University of Florida Levin College of Law

UF Law Scholarship Repository

UF Law Faculty Publications

Faculty Scholarship

2006

\title{
Tierra y Libertad: The Social Function Doctrine and Land Reform in Latin America
}

Thomas T. Ankersen

University of Florida Levin College of Law, ankersen@law.ufl.edu

Thomas Ruppert

University of Florida Levin College of Law, ruppert@law.ufl.edu

Follow this and additional works at: https://scholarship.law.ufl.edu/facultypub

Part of the Environmental Law Commons

\section{Recommended Citation}

Thomas T. Ankersen \& Thomas Ruppert, Tierra y Libertad: The Social Function Doctrine and Land Reform in Latin America, 19 Tul. Envtl. L.J. 69 (2006), available at http://scholarship.law.ufl.edu/facultypub/277

This Article is brought to you for free and open access by the Faculty Scholarship at UF Law Scholarship Repository. It has been accepted for inclusion in UF Law Faculty Publications by an authorized administrator of UF Law Scholarship Repository. For more information, please contact kaleita@law.ufl.edu. 


\title{
Tierra y Libertad: The Social Function Doctrine and Land Reform in Latin America.
}

\author{
Thomas T. Ankersen ${ }^{\dagger}$ \\ Thomas Ruppert"
}

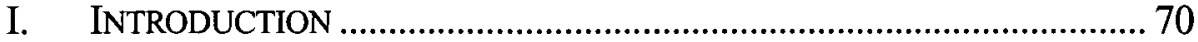

II. LAND REFORM: THE LEGAL-HISTORICAL AND

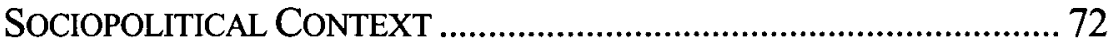

A. Roman Origins .................................................................... 73

B. Land Reform in Latin America: Historical Origins of

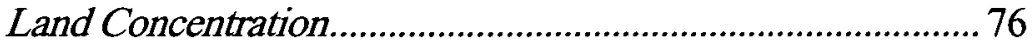

1. Pre-Colombian Land Tenure Systems............................ 76

2. Early Colonial Land Tenure Systems:

Encomienda and Repartimiento ..................................... 80

3. Colonial-Era Efforts to Address Land

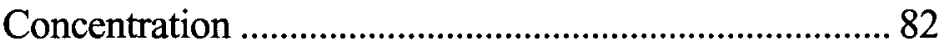

4. Initial Postcolonial Land Reform Efforts ........................ 85

III. THE SOCIAL FUNCTION DOCTRINE AS THE LEGAL BASIS FOR

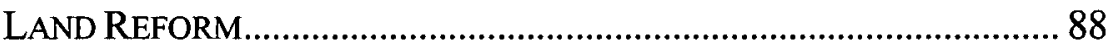

A. Competing Perspectives on the Role of Property in

Human Social Organization................................................. 88

1. The Modern Social Function Doctrine........................... 94

2. Distinguishing the Common Law's "Public Use"

Doctrine and Related Concepts in the Civil Law............ 96

B. Application of the Social Function Doctrine to Land

Reform in Latin America.

* Emiliano Zapata, the Mexican revolutionary, popularized the phrase "tierra $y$ libertad" [land and liberty], but the phrase originated in the writings of Ricardo Flores Magón. See, e.g., Tierra y libertad, http://200.39.200.70/zapata/tierra_y_libertad/tierra_y_libertad.html (last visited Mar. 3, 2006).

$\dagger \quad$ Legal Skills Professor and Director, University of Florida Joint Program in Environmental Law and Conservation Clinic. Principal Investigator, Inside the Polygon: The Efficacy of Community Tenure with the Western Property Paradigm. Support for this research was made possible by a grant from the John D. and Catherine T. MacArthur Foundation.

** Research Fellow, University of Florida Center for Governmental Responsibility, Associate Investigator, Inside the Polygon: The Efficacy of Community Tenure with the Western Property Paradigm. Other investigators working under this research and writing grant include Principal Investigator Dr. Grenville Barnes and Associate Investigator Gerald Mueller Riverstone, Ph.D. candidate. 
IV. RECENT DEVELOPMENTS AND CHALLENGES TO THE SOCIAL

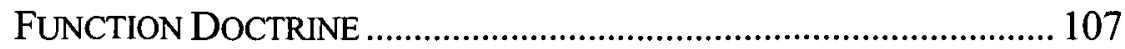

A. The International Human Rights Dimension of the Social Function Doctrine.

B. Accommodating "Sustainable Development":

Ecological Possession and the "Socio-Environmental

Function" of Land..

C. Challenges to the Doctrine from the Trade Regime:

Social Function and Regulatory Expropriation.

D. The Social Function Doctrine in the Neoliberal Era............. 114

V. CONCLUSION

\section{INTRODUCTION}

To many, the term "land reform" in Latin America conjures up images of Ché Guevara fighting an insurgency from the mountains of Latin America, of Emiliano Zapata inspiring revolution in Mexico, and of Chico Mendes holding off bulldozers with bullets to defend the rubber tapper movement in the Amazon rain forest. More recent images include Comandante Marcos exhorting Mexicans to join yet another revolution to redress poverty and landlessness in Chiapas, Venezuela's Hugo Chávez threatening to expropriate British cattle ranches for redistribution to peasant farmers, and, from another region, Zimbabwe's Robert Mugabe redistributing white farms to land-poor black Africans against a setting of development desperation. These images reflect nations and regions still held hostage by the concentration of land in the hands of a few. While real property in the developed world may no longer hold uncontested status as the most important resource a person can hold, it remains so in much of the developing world. Latin America has been caught for centuries in a vicious cycle of land consolidation and land reform; the issue perennially resurfaces since concentration of land and associated resources results in conflict.' Latin American nations are among the world's leaders when it comes to the inequality of land distribution. ${ }^{2}$

1. David Smiley, The Right to Development: Third Generation of Rights and Our Common Heritage, 2 GEOPHILOS 84, 92 (2002), available at http://www.landresearchtrust.org/ downloads/geo4/Smiley.pdf.

2. Pak Hung Mo, Land Distribution Inequality and Economic Growth: Transmission Channels and Effects, 8 PAC. ECON. REV. 171, 178, 181 (2003). Mo gives the Gini coefficients a means to measure land inequality for East Asia, Latin America, the Organization for Economic Cooperation and Development, and South Africa. Id. at 181. These show that Latin America has the most unfavorable Gini coefficient at $81.3 \%$. For a more precise breakdown of land inequality according to country, see IDRISS JAZAIRY ET AL., THE STATE OF WORLD POVERTY: AN INQUIRY INTO ITS CAUSES AND CONSEQUENCES 416-17 tbl. 11 (1992). The Gini coefficient is a measure of 
Part II of this Article briefly reviews the history of land reform, with special attention to Latin America. Land reform, ${ }^{3}$ or agrarian reform, as it is more commonly referred to in Latin America, is hardly a new phenomenon. As we will show, the need to develop a policy to redress the consolidation of lands by a powerful few and redistribute it in the name of equity and development has its pedigree in Greco-Roman times. In Latin America land reform began in colonial times and has persisted through the present, resisted by elites who benefited from the largesse of the colonial powers. In the colonial era, the land and its resources was all the crown could offer to the conquistadors, colonial elites, and to the church. As a result, the newly independent states immediately entrenched a resistant, wealthy class of latifundistas, or large landed estate holders, setting the stage for a legacy of revolution and attempts at land reform.

In Part III we discuss the legal doctrine that underpins most modern land reform in Latin America, the "Social Function Doctrine." Typically given constitutional status, the Social Function Doctrine can also be found in some Latin American civil codes and agrarian reform laws. When it is not expressly articulated, the doctrine is implicit in the language and reinforced by jurisprudence. The Social Function Doctrine can be traced to fundamentally different conceptions of the relationship between the state, its subjects and real property in society. The modern Social Function Doctrine emerged in its broadest context from the early twentieth-century writings of the French jurist and political philosopher Leon Duguit, and posits that the legitimacy of government originates in the social functions promoted by government action. While this development reflects the rise of so-called "second-generation" human rights, we also demonstrate that much deeper roots, from both preColombian and colonial times, predisposed many cultures in Latin

inequality in distribution. It ranges from zero to one; the closer to one the value is, the greater the inequality. William C. Thiesenhusen, BROKEn Promises: Agrarian REForm AND tHe LATIN AMERICAN CAMPESINO 9 tbl. 1.2 (1995).

3. Land reform has been defined as "a change of the tenancy structure under the guidance of the state and motivated by peasant pressure." JESÚS CARLOS MORETT SÁNCHEZ, Reforma AGRARIA: Del Latifundio al NeOliberalismo 25 (2003). Another generally accepted definition is that land reform means "the redistribution of property or rights in land for the benefit of the landless, tenants and farm labourers." Martin Adams, Land Reform: New Seeds on Old Ground?, 6 Overseas Dev. INST. NAT. Resources PERSP. 1 (1995), available at http://www.odi.org.uk/nrp/

nrp6.html. Agrarian reform is actually a much broader term than just land reform and includes a plethora of "rural development measures, such as the improvement of farm credit, cooperatives for farm-input supply and marketing, and extension services to facilitate the productive use of the land reallocated." Id. 
America to view property as a means to an end or a policy tool rather than an inviolable right of the individual against the state. When applied to real property, the Social Function Doctrine operates to justify a fundamentally distinct view of the role of property in society, and the rights and obligations of the individual holding property. In this sense it can be distinguished from related concepts, such as the "public use" doctrine, and its Spanish-language analog of utilidad pública. However, these distinctions have become blurred at times, just as the doctrinal distinctions between common and civil law systems have blurred over time.

Part IV discusses emerging issues that the Social Function Doctrine presents in the contemporary policy environment, as well as its adaptation in the face of new societal challenges. First employed as a tool to settle a rapidly diminishing agricultural frontier (and a safety valve to release population pressure from the urban landless), the Social Function Doctrine has had to adapt to incorporate the ecological function of property, resulting in some intriguing regional jurisprudence. And as the region's mega-cities sprawl, there are indications that the Doctrine may find new vigor in an urban context. Finally, the forces of globalization and international law present special challenges as the philosophical underpinnings of the Doctrine confront efforts to create regional free trade regimes and advance neoliberal policies.

\section{LAND REFORM: THE LEGAL-HISTORICAL AND SOCIOPOLITICAL CONTEXT}

The idea of land redistribution to address inequity can be traced to at least the ancient Greeks. ${ }^{4}$ A contemporary discussion of land reform and the pragmatic and philosophical bases for land reform benefits greatly by putting land reform in its proper historical context; to accomplish this, we go back to ancient Rome, and the foundations of modern western property law.

4. - Cf. Hans Wieling, The History of Ownership of Land, in THE PUBLIC CONCEPT OF LAND OWNERSHIP 15 (Berndvon Hoffman \& Myong-Chan Hwang eds., 1997) (noting that in early Greek societies, the state frequently reapportioned land to take account of changing demographics).

5. While the Roman model of property has often been lauded as the origin in the western tradition of private property, even during Roman times property concepts were already considered issues of public interest. J.D. van der Vyver, Ownership in Constitutional and International Law, 1985 ACTA JURIDICA 119, 134 (1985). 


\section{A. Roman Origins}

The earliest Romans held land communally among various clans.' Evidence suggests that this state of affairs held until at least the fifth century B.C. ${ }^{8}$ when the second Roman king divided the common land among the citizens. ${ }^{9}$ During the early years of the Republic of Rome, ${ }^{10}$ internal struggles between the patricians (the social class with the political power and most of the wealth) and the plebeians (the poor and disenfranchised that comprised most of the population) occupied much of the energy of Rome." Such struggles originated in part from the need for more agricultural land for both food production and as a source of livelihood for Roman citizens and conquered peoples.

Military campaigns to conquer new lands sought to solve such problems. Conquered lands were assigned the status of ager publicus, or property of the state. ${ }^{12}$ In theory these lands were to be distributed to Roman citizens lacking land. Instead, the wealthy and politically powerful class of citizens, the patricians, ended up occupying much of the ager publicus before it could be legally distributed to those lacking land. ${ }^{13}$ The patricians successfully occupied this land because Roman property law of the time only allowed the true legal owner of land-i.e., the state in the case of ager publicus - to bring an action to displace a possessor. The state, however, was composed of the same patricians who

6. Even prior to the Roman reforms, the Greeks went through early reform efforts. Elias H. TUMA, TWENTY-SiX CENTURIES OF AGRARIAN REFORM: A COMPARATIVE ANALYSIS 20-27 (1965). However, information from the period is suspect, thus leading to uncertain value of analysis of it except in the most general terms. Id. at 20. Still, in general terms, Tuma adduces the evidence to indicate that in ancient Greece, economic changes resulted in concentration of land ownership and the serfdom of many formerly free farmers, leading to demands for redistribution of land. Id. at 21-23. Upon his election as archon, or chief magistrate, in 594 B.C., Solon understood the potential danger of the growing unrest of the serfs. Id. at 23,243 . Solon thus enacted reforms eliminating existing debts, eliminating serfdom, and eliminating the ability to mortgage one's freedom to secure a debt. Id. at 23. These and other reforms of Solon did not substantially affect the distribution of land. Id. at 24. The failure of Solon's superficial reforms postponed but did not avoid revolution. Id. at 25 .

7. Wieling, supra note 4, at 15.

8. Id.

9. Id. at 20.

10. Approximately from 510 to 367 B.C. BarRY NichOlas, AN INTROdUCTION TO ROMAN LAW 3 (1962).

11. Id.

12. Andrew Stephenson, Public Lands and Agrarian Laws 10 (Herbert B. Adams ed., 1973). Early additions to the land of Rome were incorporated into the city proper as ager romanus or the public land of Rome. Id. However, after a certain point of growth, land added to Rome was no longer considered a part of the city proper and the ager romanus. Rather newly acquired land became part of the ager publicus or was given to colonies or the "municipia." Id.

13. Wieling, supra note 4, at 20. 
were occupying the ager publicus, thus leaving the "state" without motivation to eject the patricians.

De facto acceptance of this occupation-without formal legal sanction - of much of the ager publicus land by the patricians created an interest that conflicted with the concept of ager publicus lands as a resource to be given to new citizens of Rome if they did not have land or a place to build a house. ${ }^{14}$ Attempts by the state to distribute ager publicus land threatened the vested interests of the patricians with possessio $^{15}$ of such lands and would have deprived them of the wealth associated with such land. ${ }^{16}$

Ongoing occupation and possessio of land by patricians led to the development of enormous land estates, or latifundios, ${ }^{17}$ that were so extensive that the patricians needed large amounts of labor to farm them. ${ }^{18}$ The patricians were loathe to hire "freemen" to do the farming labor because freemen could be called to military duty and might thus have to abandon their work on the estate. The solution for this, from the patricians' perspective, was to use slave labor as slaves were immune from military service requirements. This "solution," however, left freemen worse off than ever: even if the freemen were not fighting a war to expand the land that would be occupied by the patricians, there was no land available to farm for themselves, nor could they get work on the large land estates since the work was being done by slaves. ${ }^{19}$

Concentration of land and wealth became so pronounced and created such poverty among the mass of Romans that calls for land reform increased along with the resistance of those with vested interests in ager publicus to resist agrarian reform. ${ }^{20}$ Some of the wealthy joined

14. STEPHENSON, supra note 12 , at 18.

15. Id. While ager publicus possessed by the patricians theoretically remained public land and the patriarchs held such lands subject to the right of the state to eject them, the fact that the patriarchs had possessio of the property gave them a right over the property superior to that of other private parties. Id. In fact, with regard to other private parties, the rights of one with possessio enabled that person to rent or sell the land like a fee-title owner. Id.

16. Id.

17. Latifundio is the Spanish word for latifundium. Latifundium is a Latin term that literally means a large private estate of real property. BLACK'S LAW DICTIONARY 898 (8th ed. 2004). Latifundio has been adopted as a legally significant term of art in Latin American land policy. For example, Venezuela defines a "latifundio" as any uncultivated or idle rural land that exceeds 5000 hectares. Presidential Decree No. 1546, Official Gazette of the Bolivarian Republic of Venezuela, No. 37,323, art. 7, Nov. 9, 2001, http://www.gobiernoenlinea.gob.ve/ docMgr/sharedfiles/294.pdf.

18. Wieling, supra note 4, at 20.

19. George Long, Agrariae Leges, A Dictionary of GREeK AND RoMAn ANTIQUTTIEs 37-44 (William Smith ed., 1875), available at http:/Penelope.uchicago.edu/Thayer/E/Roman/Texts/ secondary/SMIGRA*/Agrariae_Leges.html (last visited Jan. 25, 2006).

20. NiCHOLAS, supra note 10 , at 9. 
with the poor and dispossessed in calls for land reform as it became clear that Rome, dependent on a citizen army, could not afford to allow that same citizen base to "degenerate into a landless proletariat dependent on the rich man's dole.",11

As an early and brutal example of the threat agrarian reform posed to those occupying ager publicus, one only need look to the example of Spurius Cassius. Despite his status as a patrician, he presented an agrarian reform law, the Lex Cassia, in 468 B.C. ${ }^{22}$ The law proposed a survey which would delineate both private and public lands and proposed that the ager publicus in the survey be either distributed among the plebeians or leased for the benefit of the public coffers. ${ }^{23}$ While the Lex Cassia technically became law, it was never enforced. ${ }^{24}$ The law provoked such outcry and passion that, at the end of his term in office, Spurius Cassius was sentenced to death. ${ }^{25}$ In 376 B.C., Licinius proposed the Lex Licinia. This law limited the amount of land that any one person could possess to 300 acres. $^{26}$ It also limited the number of cattle that any one person could graze on the public commons. ${ }^{27}$ The Licinia Sextia, which was passed in 367 B.C., also limited the amount of ager publicus that one person could own and put limits on the amount of livestock an individual could pasture on public land. ${ }^{28}$ Like previous efforts at land reform, these laws had little practical effect.

In 133 B.C. another agrarian reform effort emerged. Presented "[by] tribune Ti. Sempronius Gracchus [the Lex Sempronia] create[d] allotments of the large area of public land acquired after the Second

21. Id.

22. STEPHENSON, supra note 12, at 24. This book gives the date of the Lex Cassia as 268 B.C. This is a typographical error as the correct date is 468 B.C. See, e.g., Online Encyclopedia -Cassius, http://encyclopedia.jrank.org/CAR_CAU/CASSIUS.html (last visited Mar. 3, 2006).

23. Id.

24. Id. at 25 .

25. Id.

26. Id. at 38. Licinius, despite a hundred years of failures of agrarian reform, pushed this law regardless of its draconian effect on the wealth of the patriarchs. Licinius thought he could unite the rich and poor plebeians by simultaneously presenting another law that would give plebeians increased political representation and power. This was designed to appeal to the rich plebeians that preferred to be "upstarts among the patricians rather than leaders among the plebeians" while the land reform and distribution would appeal to the poor. Id. at 37-40. But this strategy failed and the patricians united in opposition. Finally, after many years of continuing political struggles, Licinius managed to get the laws passed. Id. at 40-44. The laws, however, failed to have their intended beneficial effects as compliance was virtually nonexistent and the rich got richer as the poor got poorer.

27. Id. at 38.

28. See id; see also CQD Leges Certaminabiles, http://www.geocities.com/bwduncan/ rhr/leges.html\#367 (last visited Mar. 5, 2006). 
Punic War. The new allotment holders paid a small quit-rent and promised not to alienate their plot for a certain term of years. [The law] also [upheld] previous land limits of 500 iugera., ${ }^{, 29}$ The small allotments to those without land and the prohibition on alienation of small land allotments sought to guarantee the use of these allotments by the recipient for agriculture on the assumption that this would improve the situation of those receiving the allotments. ${ }^{30}$ Like other agrarian reforms, this one met with fierce opposition, and its proponent was slain soon after the law took effect. ${ }^{31}$

In sum, the ancient Roman state attempted land reforms as a means to address the concentration of land and the conflicts arising out of resulting landlessness and poverty. Unfortunately, these first western attempts at land reform largely failed due to entrenched interests, a policy failure that would be repeated in the ensuing millennia. We turn now to the Latin American experience.

\section{B. Land Reform in Latin America: Historical Origins of Land Concentration}

Soon after the conquest of the New World, the problem of land concentration became manifest throughout Latin America. This Part traces some of this history and the reasons for land concentration in the region. This review suggests that the concentration of land in Latin America developed as a result of the conquest, and its relationship to the indigenous inhabitants of the region. Colonial tenure regimes perpetuated patterns of land concentration which have persisted through the era of independence to the present day.

\section{Pre-Colombian Land Tenure Systems}

In significant parts of Latin America the Spanish arrived to find complex indigenous societies with highly evolved tenure systems. Many of the largest indigenous cultures in Latin America had land tenure systems that vested power over land in elites, and offered parallels to

29. See Leges Certaminabiles, supra note 28; see also STEPHENSON, supra note 12, at 69. Ironically the law seems to reward those who wrongly appropriated ager publicus for private use by granting private ownership to the occupiers of up to 500 iugera of ager publicus. STEPHENSON, supra note 12 , at $69-70,73$. An iugerum equals about 2500 square meters. Wieling, supra note 4 , at $21 \mathrm{n} .25$.

30. STEPHENSON, supra note 12 , at 70 .

31. Id. at 73 . 
feudal tenure in Europe. ${ }^{32}$ One commentator has compared preColombian Andean land tenure, which the Spanish co-opted, to the Spanish rural comuna of the sixteenth century. ${ }^{33}$ Some historians speculate that the European conquest was hastened by the ability of the conquistadores to co-opt the tenure regimes already in place, merely substituting themselves for indigenous elites. ${ }^{34}$ While this analogy oversimplifies the nature and diversity of indigenous land tenure in precolonial America, it does seem to hold true for the more powerful and complex indigenous societies such as the Aztec, Inca, and Maya, who were themselves conquering powers.

In coastal and northern Mexico the Aztecs developed a property regime that shared characteristics of western notions of ownership. ${ }^{35}$ For example, all Aztecs, like all Romans, theoretically had a right to possess land. ${ }^{36}$ The Aztecs in Mexico also had a social organization in which land, held by the community, would be allotted to families according to need. ${ }^{37} \quad$ Limited land rights were distributed as a reward for military achievement, but even these rights were only "private" to the individual for the individual's life since the property returned at death to the community. ${ }^{38}$ When warriors received lifetime property as a reward for military service, this included possession of the people on the land and their labor, ${ }^{39}$ foreshadowing the Spanish encomienda system. ${ }^{40}$ Aztec elites altered this system in their own favor by eliminating redistribution at death in favor of inheritance and began accumulating ever larger tracts of land for themselves. ${ }^{41}$ Thus, some latifundios in Mexico represent successors to large Aztec estates. ${ }^{42}$

32. See, e.g., JOHN P. POWELSON, THE StORY OF LAND 220 (1988) (noting the similarities in socioeconomic and land tenure structures between the Spanish and the Aztecs at the time of the Spanish conquest).

33. José Maria Arguedas, Las Comunidades de España y del Perú (1968).

34. E.g., G. MCCUTCHEN MCBRIDE, THE LAND SYSTEMS OF MEXICO 121, 123 (1923); see also POWELSON, supra note 32, at 220.

35. See, e.g., Placido Gomez, The History and Adjudication of the Common Lands of Spanish Mexican Land Grants, 25 NAT. RES. J. 1039, 1047, 1051-53 (1985); see also MCBRIDE, supra note 34 , at 121 .

36. See, e.g., Frank Tannenbaum, The Mexican Agrarian Revolution (1930); see also POWELSON, supra note 32 , at 219 . Of course "all" here means males of a certain level of social and political status.

37. EYLER N. SIMPSON, THE EJIDO: MeXICo's WAY OUT (1937).

38. POWELSON, supra note 32, at 219.

39. Id. at 219; cf. MCBRIDE, supra note 34, at 120.

40. See infra Part II.B.2.

41. See POWELSON, supra note 32, at 219; see also SIMPSON, supra note 37, at 17.

42. MCBRIDE, supra note 34, at 122. 
Pre-Colombian Andean societies also demonstrated a similarly complex land distribution dynamic. ${ }^{43}$ Despite centuries of control by the Inca state, the Spanish Crown, and modern national governments, the predominant land tenure unit today in Quechua and Aymara Indian regions of Andean Peru and Bolivia remains the small semiautonomous community known at the ayllu. ${ }^{44}$ While the community-level land-tenure system has certainly undergone changes over the centuries, many Andean communities still retain aspects of this system that likely date to pre-Inca times. ${ }^{45}$ During the period of expansion of the Inca Empire, the Inca lords used a strategy that the Spanish would subsequently adopt: the absorption of preexisting land tenure and social structures. The Inca maintained structures, such as the ayllu, largely intact, while shaping these structures to meet the needs of the expanding Inca Empire. ${ }^{46}$ Locallevel chiefs, or kurakas, were kept in power, and served as intermediaries between the ayllus and the Inca. ${ }^{47}$

During the Inca period, while lands and usufruct rights were controlled by individual ayllus, all land was apparently considered to be the property of the Inca State. ${ }^{48}$ Ayllu lands were divided into three parts, each having well-established boundaries: one part for the state, one part for supporting priests and religious ceremonies, and one part for the community. ${ }^{49}$ In addition to other requirements of citizenship (such as military service and unpaid labor for the Incan state), community members were required to work on the portions of community land dedicated to the Incan state and religious hierarchy, under the supervision of local lords, in order to provide agricultural tribute. ${ }^{50}$

Analogies to the colonial Spanish tenure regime are difficult to escape. Indeed, just as the Inca had used conquered enemy political power and power structures to their advantage in building their empire,

43. See Maria Rostworowoski de Diez CaNSECo, History of THE INCA REALM (1999).

44. Arij Ouweneel, The "Collapse" of the Peruvian Ayllu, in IMAGING THE ANDES: Shifting MARGins IN A MARgINAL World 81, 92 (Ton Salman \& Annelies Zoomers eds., 2003); cf. Pedro Germán NúÑez Palomino, Derecho y Comunidades Campesinas EN El Perú 19691988 , at 9, 39 (1996) (noting that the Spanish took advantage of the ayllu structure rather than destroying it).

45. PALOMINO, supra note 44, at 65-66.

46. See Herbert S. Klein, Hacienda and Ayllus: Rural Society in the Bolivian ANDES IN THE EIGHTEENTH AND NINETEENTH CENTURIES (1993).

47. Id. at 10.

48. PALOMINO, supra note 44 , at 37-38.

49. Id. at 38 .

50. Jane Benton, Agrarian Reform in Theory and Practice: A Study of the Lake TITICACA Region of Bolivia 21 (1999); W.E. Carter, The Ambiguity of Reform: Highland Bolivian Peasants and Their Land (1963) (Ph.D. dissertation, Columbia University) (copyright 1967, published by University Microfilms 1974). 
the Spanish did the same with the Inca. For example, ayllu leaders, called jilaikatas, often served as mayordomos, or managers, on Spanish haciendas. ${ }^{\text {s1 }}$ From very early on in its colonial history, land was highly concentrated in the Peruvian altiplano, in part because land ownership had been concentrated among the Incas. ${ }^{52}$

Less information exists about Mayan tenure systems. From the limited evidence available, it appears that the elite held a privileged status with regard to land and a representative of the King had the power to allocate and reallocate land to families for use. ${ }^{53}$ Uncertainty regarding early Mayan tenure is compounded by the fact that the Spanish arrived after the collapse of the Maya Empire, when Mayan society had already abandoned their lowland city-states and dispersed to the highlands of Mesoamerica. However, indigenous social organization and land tenure structures in the highlands of early colonial Guatemala apparently shared many similarities with those of Andean society. ${ }^{54}$ The basic juridicalsocial unit was known as the chinamit (in Quiche-Kackchiquel language), "controlled by indigenous caciques through the cabildo or municipal council, and claiming descent from a common ancestor."ss The Spanish referred to this land tenure unit as a parcialidad ${ }^{6}$ and coopted the structure as a way for the Spanish to exercise power over the Maya people.

These three indigenous groups, the Aztec, Inca, and Maya, were the most structurally complex societies of pre-Colombian America, but they still only comprised a fraction of the Latin American indigenous population and geographic distribution. Even so, it was with these societies that the Spanish had the most sustained interaction. The

51. KLEIN, supra note 46, at 16. A hacienda is a "large landed estate, an 'economic entity devoted to supplying local markets with both grain and animal products."' M.C. Mirow, Latin American Legal History: Some Essential Spanish Terms, 12 LA RAZA L.J. 43, 45 (2000).

52. POWELSON, supra note 32, at 236 (noting that often large blocks of land would be given in a single grant if a block of land was already organized under the Inca landholding system). Powelson also notes, however, that while land ownership was concentrated, use of the land was not so concentrated. Id. at 237-38.

53. Id. at 217; see also Robert M. Hill, II, Colonial CakChiQuels: Highland Maya ADAPTATION to SPANISH RULE 1600-1700, at 48-49 (1992). Hill also notes similarities between Maya and Spanish landholding systems such as the commoners' usufruct rights being limited to tracts under cultivation. HILL, supra, at 50.

54. Ouweneel, supra note 44 , at 88.

55. Id. (citing Robert M. Hill \& J. Monaghan, Continuities In Highland Maya Social Organization: Ethnohistory in SaCapulas Guatemala (1987)). In the Yucateca Maya region of Southern Mexico the sociopolitical-tenurial unit was known as the cah, but possessed similar characteristics to the chinamit. Id. at 89 (citing MATTHEw Restall, THE MAYA WORLD: YUCATEC CULTURE AND SOCIETY, 1550-1850(1997)).

56. Ouweneel, supra note 44 , at 88 . 
Crown's ability to co-opt the tenure system of the indigenous elites not only hastened conquest, it may also have sown the seeds for emergence of the skewed land distribution that continues to plague the region.

\section{Early Colonial Land Tenure Systems: Encomienda and Repartimiento}

Encomiendas and repartimientos were typical early tenure practices of the Spanish in Latin America and were used to encourage conquest and reward favorites of the Crown or those empowered by the Crown to give grants. A grant of a right to use an area coupled with the right to receive tribute of the indigenous people occupying these lands was known as an encomienda. In "exchange" for the tribute of indigenous peoples to the grantee of the encomienda, known as an encomendero, laws specifically required the encomendero to protect and Christianize the indigenous peoples as well as ensure that they were permitted to use their land for their own subsistence. ${ }^{58}$ In reality, any obligations of encomenderos were little respected and often encomenderos encroached on indigenous lands the law obligated them to protect. ${ }^{59}$

Technically an encomienda did not give the encomdero ownership of the land, but only granted a right to demand tribute from Indians in the area covered by the encomienda. ${ }^{60}$ Like other supposed limitations on the doctrine of encomienda, this had little relation to reality, and encomenderos often treated encomiendas as alienable private property. ${ }^{61}$ This meant that encomiendas were often divided, sold, or mortgaged in violation of the law. ${ }^{62}$ In addition to the concentration promoted by large land grants, many grants were also made under questionable authority or

57. Akio Sato, Legal Aspects of Landownership In Colonial SPanish AMERICA 1920 (1976). See generally L.B. Simpson, ThE ENCOMIENDA IN NEW SPAIN (rev. ed. 1966).

58. SATO, supra note 57 , at 19.

59. Id. Encomiendas and repartimientos resembled another Spanish tradition from the "Reconquest" period in Spain: the adelantado. During the Reconquista, when the Moorish invaders were repelled, those that pushed to the frontier and took control of land were given special rights, the adelantado, often military in nature, to govern that land. The adelantado was a typical medieval institution. José M. OTS CAPDEQUí, EL RÉGIMEN DE LA TIERRA EN LA AMÉRICA ESPAÑola DURANTE EL PERIOdO COLONIAL 12 (1946). This was essentially the same type of reward that would be given to the explorers and conquerors of the New World even though the concept of adelantado had already ceased in Spain. Id:; see also PowELSON, supra note 32, at 201.

60. SATO, supra note 57 , at 19.

61. Id.

62. Such a divorce between official law and reality was common during the colonial period of Latin America. See, e.g., OTS CAPDEQUi, supra note 59, at 6-17; PALOMINO, supra note 44 , at 39 (noting that the Spanish were unable to effectively enforce Crown laws protecting the Indians from abuses of the encomenderos). 
laws, often involving bribery. ${ }^{63}$ These problematic beginnings for European land rights in the New World continue to cast a long shadow on the legitimacy of land tenure throughout the region. ${ }^{64}$

It is difficult to accurately distinguish between repartimientos and encomiendas in many respects. ${ }^{65}$ Colonial-era documents frequently used the terms interchangeably. ${ }^{66}$ One distinction is that, technically speaking, repartimiento has a broader meaning since a repartimiento included everything in an encomiendo (the right to demand tribute, for example) and could also give rights to the grantee to demand that the indigenous inhabitants of an area labor in mines, cultivate crops, or construct public works. ${ }^{67}$ Repartimientos varied from grant to grant ${ }^{68}$ and often included the authority to divide and parcel out the land as well as to appoint public officials. ${ }^{69}$ Like encomiendas, a repartimiento did not convey clear title to the land in the grant. ${ }^{70}$ Rather, repartimientos were a reflection of feudal notions of landholding that were already extinct in Spain during the colonial period."

Recipients of Spanish grants often abused their authority. Eventually the inherent tension between the rights to property asserted by encomenderos and the far more limited rights actually intended by the Crown resulted in a power struggle between the Crown and encomenderos. ${ }^{72}$ For example, the massive grants of the New World were originally intended to be only for the life of the recipient. As estates of the encomenderos grew, so did the power of these great landholders, the colonial "lords of the manor." " In the face of this growing threat, the Crown sought to divide large landholdings in order to subdue the power

63. E.g., POWELSON, supra note 32, at 242.

64. Id. (noting this dynamic in Argentina).

65. JOSÉ M. OTS CAPDEQUí, ESTUDIOS DE HISTORIA DEL DERECHO ESPAÑOl EN LAS INDIAS $102(1940)$.

66. Id.

67. Id. at 102-03.

68. Id. at 38 .

69. OTS CAPDEQUi, supra note 59, at 12; POWELSON, supra note 32, at 235-36 (noting that in 1529 Pizarro received authorization to conquer Peru along with authority to allot lands, apportion the indigenous population, and appoint public officials).

70. SATO, supra note 57, at 3-4; Lisandro D. Hormaeche, El sistema de encomienda como aparato de control de la mano de obra indigena y de aculturación en el espacio Hispanoamericano (Siglos XVI y XVII) § 4, http://www.monografias.com/trabajos 14/sistemaencomienda/sistemaen comienda.shtml. A repartimiento was not itself title to land, but rather an expectation of title if certain conditions were met. OTs CAPDEQUi, supra note 65, at 38-39.

71. OTS CAPDEQUf, supra note 59 , at 12 (noting that the authority of conquerors to make grants represented the influence of medieval Spanish feudalism that was already extinct in Spain).

72. Id. at 15-16.

73. Encomenderos sought increased political autonomy, for example. PALOMINO, supra note 44 , at 39 . 
of the encomenderos. The representatives of the Crown charged with carrying out this task were, however, some of the largest encomenderos and thus not inclined to obey the Crown's wishes-the same conflict-ofinterest dynamic confronted by the Roman state almost two millennia earlier. Furthermore, many of the judges in the tribunals and other representatives of Crown authority were more steeped in Justinian Roman law concepts of law and absolute private property ownership than they were in feudal notions of tenure and its more limited rights associated with land holding. ${ }^{74}$ As a compromise, and to maintain the support and allegiance of encomenderos, the Crown finally agreed to extend encomiendas from "the life of the encomendero" to "two lives." This still did not end the conflict and encomienda rights continued to receive periodic extensions until "temporary" encomiendas had effectively become permanent. ${ }^{75}$

Thus, in comparing the land tenure systems of the largest and most complex pre-Colombian cultures in the New World with those introduced by the Spanish, scholars have noted certain similarities. Indigenous and Spanish systems both possessed elements of feudalism. Also, some indigenous groups were already accustomed to paying tribute to those who had conquered them. ${ }^{76}$ There appears to be some agreement that these similarities in tenure systems of the Spanish and indigenous populations facilitated the imposition of the encomienda system on significant segments of the indigenous population. ${ }^{77}$

\section{Colonial-Era Efforts to Address Land Concentration}

The Spanish Crown's early policy of land for conquest through repartimiento and encomienda inevitably led to the inequitable distribution of land in much of the New World. This concentration of land holdings in colonial elites led to an early realization by the Spanish Crown that latifundios, the scourge of Roman land tenure, now dominated New World land tenure. ${ }^{78}$ As the Crown grew increasingly

74. OTS CAPDEQUi, supra note 59, at 17, 77-78.

75. J. Parry, The Establishment of the European Hegemony 61 (3d rev. ed. 1966) (noting that settlers pressed the Crown to make encomiendas entailed estates).

76. See, e.g., Hormaeche, supra note $70, \S 3$ (citing CHARLES GIBSON, LAS SOCIEDADES INDIAS BAJO EL DOMINIO ESPAÑOL 157-88 (1990)); MICHAEL BUSBIN, ENCOMIENDA SYSTEM AND THE NEW WORLD INDIANS, http:/historicaltextarchive.com/sections.php?op=viewarticle\& artid=633 (last visited Jan 16, 2006).

77. See, e.g., M.C. Mirow, Latin American LaW: A History of Private LaW and INSTITUTIONS IN LATIN AMERICA 1, 6-7 (2004).

78. The Spanish Crown's concern with the growing power of the latifundio owners echoed the problem of the Roman state more than a millennia before: 
concerned about the proliferation of latifundios, the Crown began to manipulate property rights and land policy to address the problem and to stimulate development, beginning a legacy of state intervention in land tenure and property rights that continued through independence to present day Latin America, and foreshadowing the emergence of the Social Function Doctrine in the region. When the Crown's interests shifted from conquest to stabilization of new populations in conquered areas, it promoted more permanent settlements and agricultural production by attaching conditions to further grants of interests in land. ${ }^{79}$ Thus, for example, the Crown made inalienable small grants in Mexico that had to be cultivated within two years or returned to the Crown. ${ }^{80}$ Similarly, the Crown actively sought to encourage a pattern of small landowners working the land in Peru. ${ }^{81}$ Ultimately, however, Crown policies aimed at more stable, permanent settlements and agricultural production by independent landholders failed to displace the entrenched notion of landed wealth held by colonial elites. ${ }^{82}$

In 1591, the Spanish Crown embarked on its first "agrarian reform" in the New World. ${ }^{83}$ Under this "reform" the Crown would reclaim all lands under its control that lacked "just and true title." ${ }^{94}$ Like ancient Rome before it, and myriad efforts that would follow it, the reform sought to clarify existing rights and provide tenure security on legally acquired lands. ${ }^{85}$ This was accomplished through the composicion, or confirmation of land title, ${ }^{86}$ which essentially was a fee paid to the Spanish Crown to legally recognize existing use of lands and issue a valid title. ${ }^{87}$ The composición fundamentally relied on the notion that all

If private individuals acquire very large amounts of land the resulting economic power tends to become transformed into political power. The ownership of land turns into lordship over the land, the owner of the land assumes the functions of the state and becomes a power factor which threatens and limits the authority of the state.

Wieling, supra note 4, at 22 .

79. OTS CAPDEQUí, supra note 59, at 27-28.

80. POWELSON, supra note 32, at 220.

81. Id. at 237-38.

82. OTS CAPDEQUí, supra note 59, at 51-52 (noting policy decreeing smaller grants of land to avoid the problems of latifundios).

83. Id. at 67.

84. Id. at 70 (citing Libro IV, título XII, Ley 14 of RECOPILACIÓN DE LAS LEYES DE LOS REINOS DE INDIAS 1680 as a codification of the Royal Decree of 1591).

85. See MCBRIDE, supra note 34, at 56 (2d ed. 1927).

86. Id.

87. Composicion was a reaction both to the Crown's need to begin generating revenue through land alienation rather than giving it away and as a way to address the reality of extensive illegal occupation of land. SATO, supra note 57, at 9-10. Thus, the composición envisioned an 
land belonged inherently to the Crown of Spain, ${ }^{88}$ and that only through a grant of rights from the Crown could one have any legal right to land. ${ }^{89}$ The composicion theoretically required delimitation and demarcation of the land to be titled, but typically the estates were so large that this presented virtually insurmountable challenges. ${ }^{90}$ This suggests that this composición was less intent on effective land redistribution than on raising funds for the Spanish Crown ${ }^{91}$ as well as to address titling confusion. ${ }^{92}$ Interestingly, the reform also explicitly legitimized some current land holdings that were not properly granted. ${ }^{93}$ Despite such early and half-hearted attempts at land reform, land concentration and tenure insecurity continued to plague Latin America throughout the colonial period. ${ }^{94}$

Brazil merits separate consideration in this context as it fell under Portuguese rather than Spanish rule. Though some of the colonial drivers differed, Brazil was not immune from the latifundio legacy. Early disinterest in real colonization led the Portuguese crown to offer generous, relatively unencumbered land grants referred to as sesmarias..$^{95}$ The only caveat to these crown grants was a reversionary clause in the event the property was not cultivated and put to "beneficial use," a requirement that foreshadows much of the country - and region'ssubsequent land policy problematic. ${ }^{96}$ Despite the presence of this social

assessment of lands, payment of a fee for lands not legally belonging to the possessor, and issuance of title. Id; see also OTS CAPDEQUi, supra note 59, at 68-73.

88. OTS CAPDEQUí, supra note 59, at 27.

89. See, e.g., Libro IV, titulo XII, Ley 14 of RECOPILACIÓN DE LAS LEYES DE LOS REINOS DE INDIAS 1680 as a codification of the Royal Decree of 1591 ("Por haber Nos sucedido enteramente en el señorio de las Indias y pertenecer a nuestro patrimonio y corona real los valdios, suewlos y tierras, que no estuvieren concedidos por los señores Reyes nuestros predecesores, o por Nos, o en nuestro nombre, coviene que toda la tierra, que se posee sin justos y verdaderos títulos, se nos restituya, según y como nos pertenece." ["Because we are the successors in seigniorality [dominion] over the Indias [New World], the Indias are now part of our patrimony and our Royal Crown owns all vacant areas, soils and land that were not granted by the kings that were out predecessors or in our name or by Us; thus, all lands not held by virtue of a true and just title issued by one of these authorities must be returned to Us as it is our land." (Thomas Ruppert trans.)]).

90. MCBRIDE, supra note 34, at 56-57 (2d ed. 1927).

91. OTS CAPDEQUí, supra note 59, at 115, 130.

92. Cf. id. at 70-71.

93. Id. at 71. Corruption often included grants of lands by cabildos or city councils. See, e.g., SATO, supra note 57, at 6-8.

94. OTS CAPDEQUI, supra note 59, at 107-08.

95. LeE J. Alston, GaRY D. LibeCAP \& BERNARDO MuELler, TITLES CONFLICT AND LAND USE: THE DEVELOPMENT OF PROPERTY RIGHTS AND LAND REFORM ON THE BRAZILIAN AMAZON FRONTIER 34 (1999).

96. Id. 
function precursor, reversions did not occur, and Brazil embarked on a path of land concentration that has few rivals globally. ${ }^{97}$

\section{Initial Postcolonial Land Reform Efforts}

As the countries of Latin America gained their independence in the nineteenth century, the colonial legacy of encomiendas and latifundios persisted, typically metamorphosing into haciendas. ${ }^{98}$ Haciendas greatly resemble their colonial predecessors but typically lacked the right to exact tribute. ${ }^{99}$ The monopoly of land by hacendados led newly independent states to engage in land reform. This Part offers some brief examples.

Mexico attempted its first land reform soon after independence in 1821. A key feature of this early reform attempt was the confiscation of large tracts of land from the Catholic church in the mid 1800s. ${ }^{100}$ This reform also led to settlement of some empty lands but failed to realize the goal of widespread small landholdings. ${ }^{101}$ This initial failure engendered further efforts at reform as the 1910 Mexican revolution ended the thirty-four-year rule of Porfirio Díaz, known as the "Porfiriato." In the General Agrarian Law of 1915, article 1 stated that "the existence of large territorial lands is considered incompatible with the peace and prosperity of the Republic."102 Article 3 of this law declared the public utility of breaking up excessively large estates..$^{103}$ Article 8 did, however, also contemplate compensation for expropriated land, ${ }^{104}$ something often overlooked by critics of the Mexican Revolution.

97. Id.

98. See Rani T. Alexander, Introduction: Haciendas and Agrarian Change in Rural Mesoamerica, 50 ETHNOHISTORY 3, 3-6 (2003). A hacienda is "large landed estate, an 'economic entity devoted to supplying local markets with both grain and animal products."' Mirow, supra note 51 , at 63 .

99. Haciendas were large areas (usually from 1,000 to 100,000 hectares with an average of 3,000 hectares) possessing many different types of agricultural land and activities that an absentee landowner managed and cultivated through hired management. SIMPSON, supra note 37, at 489-90. Haciendas were often largely self-sufficient and housed a permanent labor force. Id. However, both of these attributes have changed as large farms have become more mechanized. THIESENHUSEN, supra note 2, at 8 . One common way for hacendados to ensure that the resident labor supply, usually composed of Indians, remained on the hacienda was to loan money to the laborers or require that they only purchase in script at the equivalent of the company store, thus utilizing laws of debt peonage to bind Indian laborers to the land. SIMPSON, supra note 37, at 1617, 38-39.

100. POWELSON, supra note 32 , at 227-28.

101. Id. at 228.

102. SÁNCHEZ, supra note 3 , at 47.

103. Id. at 48 (emphasis added) (in Spanish: utilidad pública).

104. Id. 
In Peru, shortly after independence, an effort to remake the Inca into small landholder/farmers in the image of the Europeans failed. Laws intended to help the Inca actually led to greater loss of their land and continued concentration of land in the hands of wealthy latifundistas. $^{105}$ The legal means by which land concentration continued in Peru in the nineteenth and twentieth centuries remains unclear; evidence appears to indicate that enlargement of landholdings likely occurred through extralegal appropriation by powerful private landowners. ${ }^{106}$

In Argentina, early emphasis on cattle ranching led to the emergence of latifundios at the expense of cultivated crops. The lack of access to land and food resulted in a very early attempt at agrarian reform in the mid-1820s in Argentina. The president promulgated a law of emphyteusis ${ }^{107}$ that did not allow alienation of state land for thirty-two years. During this time, the land was rented, at minimal rent, to small holders; at the end of the thirty-two-year period, the government was obligated to sell or grant the land, preferably to those that had already been using it. ${ }^{108}$ Once the proponent of this plan had been overthrown however, the program was perverted to the ends of the latifundistas. One family alone received over 864 square kilometers of land. ${ }^{109}$ The emphyteusis laws were further altered to favor individuals who had acquired extensive lands by extending the period of possession indefinitely and lowering rents. ${ }^{110}$ Later attempts at diversifying land ownership proved no more successful than the emphysteusis laws.

In 1822, just months prior to independence, Brazil abolished the Portuguese-inspired Sesmaria system, but failed to replace it with a new land law. ${ }^{11}$ Instead, the new nation's still plentiful land was "distributed" under the legal doctrine of "posse" or occupation." position to benefit initially from this frontier doctrine were latifundistas

105. Powelson, supra note 32, at 238-39.

106. Id. at $239-40$.

107. Emphyteusis is "a long-term (many years or in perpetuity) rental of land or buildings including the exclusive enjoyment of all product of that land and the exercise of all property rights typically reserved for the property owner such as mortgaging the property for the term of the emphyteusis or permitting a right of way." Duhaime's ONLINE LEGAL DiCTIONARY, http:// duhaime.org/dictionary/dict-e.aspx (2004) (last visited Jan. 31, 2006). Furthermore, this perpetual leasehold may be alienated or inherited and may not be taken back by the "owner" as long as the leaseholder pays the rent. Wieling, supra note 4 , at 20-22.

108. POWELSON, supra note 32, at 243.

109. Id.

110. Id. at 244.

111. Jose Heder Benatti, Posse Agroecologica \& Manejo Florestal a luz da Lei 9.985/00, at 65 (2004).

112. Id. 
with the capacity to occupy and defend their claims. ${ }^{113}$ Brazil passed its first land law in 1850, first legitimizing all sesmarias and posses, then abolishing the legal basis for the latter. ${ }^{14}$ Abolition of posse was designed in part to secure latifundios from the waves of encroaching squatters who could themselves assert posse. ${ }^{115}$ In 1889 jurisdiction over land policy transferred to the Brazilian states, which set out to alienate state lands, though this did not greatly affect the actual distribution of lands, which remained concentrated in large landholdings. ${ }^{116}$ As the twentieth century unfolded, available public land for distribution to the landless diminished and the Brazilian government began to covet the latifundios, and the beneficial use doctrine reemerged as a basis for expropriation-often with little or no compensation. ${ }^{117}$ Despite these efforts land reform in Brazil's early postcolonial era was largely considered a failure. ${ }^{118}$

In summary, on the eve of the twentieth century, Latin America already had a long and troubled history of state efforts to manipulate property rights to alleviate the conflicts and problems inhering in concentration of land. Early in the colonial period the Crown used its power to structure property law to encourage conquest and co-opt indigenous tenure regimes. It later sought to manipulate land policy and property law to diminish the growing power of the colonial elites, to encourage permanent colonization and agriculture, and to create a new source of revenue through a fee-based process for regularizing title. By the early postcolonial period, the newly independent countries of Latin America were continuing the tradition of land reform, seeking to alleviate the social problems associated with land concentration and its attendant landlessness. These efforts began well before the modern introduction of the Social Function Doctrine into the lexicon of political philosophy, and its incorporation into land policy. Still, the precedent for the mechanism through which the Social Function Doctrine would manifest itself, state manipulation of private property rights ${ }^{119}$ had been

113. ALSTON, LiBECAP \& MUELLER, supra note 95, at 34-35.

114. BENATTI , supra note 111, at 66; Alston, LiBECAP \& MUELLER, supra note 95, at 3435.

115. ALSTON, LiBECAP \& MUELLER, supra note 95, at 35.

116. Id. at 36 .

117. Id. at 37-38. This, of course, does not consider the vast forests of the Brazilian Amazon, which remained beyond the reach of colonization and Brazilian land policy until the second half of the twentieth century.

118. Id.

119. Cf, e.g., OTS CAPDEQUI, supra note 59, at 77 (comparing treatment of private property during colonial times with the Social Function Doctrine of modern times). 
firmly established in Latin America. The Social Function Doctrine would offer a philosophical and juridical basis to continue these policies.

\section{THE SOCIAL FunCtion Doctrine AS THE LEGAL BASIS FOR LAND REFORM}

In the early twentieth century, inequitable land distribution in Latin America converged with the emergence of European socialist ideology and spawned revolutionary fervor in the region. In most of Latin America the encomienda and repartimiento systems had been replaced by the hacienda system, perpetuating a two-class society of landed and landless. ${ }^{120}$ Several Latin American countries top the list in unequal distribution of land. In Brazil, for example, two percent of the farm operators held over half the farmland. ${ }^{121}$ The Mexican Revolution, in particular, represented a direct assault on the hacienda system. The most significant factor fomenting the 1910 revolution was inequitable land distribution. ${ }^{122}$ In 1906 a group of liberals opposed to the dictatorship of Porfirio Díaz published the "Programa del Partido Liberal Mexicano," or "Platform of the Liberal Party of Mexico," which stated that "owners of land are obligated to ensure that all of their land is productive; any part that is not productive may be seized by the state." ${ }^{\text {,123 }}$ Revolutionary leaders called for expropriation of the haciendas and redistribution of hacendado land to a growing mass of landless peasants. The revolutionaries argued that fallow land locked up in haciendas was not benefiting society and obligated the state to once again intervene in property relations. The emerging Social Function Doctrine would justify the exercise of that obligation.

\section{A. Competing Perspectives on the Role of Property in Human Social Organization}

Rather than viewing the state as a supposedly neutral arbiter of private property relations through land titling, registration and market regulation, the Social Function Doctrine suggests a significantly greater role for state action in affirmatively employing land policy to effect social change. This Part provides the philosophical background for the development of two contrasting views of the role of property and the

120. MCBRIDE, supra note 34, at 65 (2d ed. 1927) (noting that the Mexican Revolution was in part a result of the division of society into a miniscule landowning class and a very large landless class).

121. THIESENHUSEN, Supra note 2 , at 8 :

122. SIMPSON, supra note 37 , at 43.

123. Jorge Mario Magallón IbarRa, Derechos del PROPIETARIo 12 (2002). 
state. We then distinguish and compare treatment of the public's interest in individual real property under the "public use doctrine."

Political systems fall somewhere along a continuum describing property rights. ${ }^{124}$ At one extreme reside systems that simply do not contemplate individual ownership of real property ${ }^{125}$ these, to the extent they exist, do not form part of our discussion. At the other extreme of the property continuum lies a system where individual property ownership vests independently of the existence of states and where the state has no ability to limit the actions of property holders. While it is equally likely that such a system does not exist, ${ }^{126}$ its closest analog may be what is characterized as allodial tenure. Allodial land is land held in absolute ownership and which gives rise to no obligations on the part of the owner to anyone else. ${ }^{127}$ The notion of allodial tenure has captured the imagination of some libertarians and individuals in the contemporary

124. For examples of expressions of the continuum, see Steven E. Hendrix, Property Law Innovation in Latin America with Recommendations, 18 B.C. INT'L \& COMP. L. REV. 1, 5-6 (1995); Heather Boyle, The Land Problem: What Does the Future Hold for South Africa's Land?, 11 IND. INT'L \& COMP. L. REV. 665, 673 n.74 (2001) (quoting John D. Montgomery, Land Use as an International Issue, in INTERNATIONAL DIMENSIONS OF LAND REFORM (John D. Montgomery ed., 1984) ("Most Atlantic countries regard land as a form of personal property; most of Eastern Europe considers it a collective good.")); $c f$. UNIV. OF MINN. HuMAN RIGHTS RES. CTR., CIRCLE OF Rights-ECONOMIC, SOCIAL AND CULTURAL RIGHTS ACTIVISM: A TRAINING RESOURCE, MODULE 18: LAND RIGHTS (2000) [hereinafter CIRCLE OF RIGHTS], available at http:/wwwl umn. edu/humanrts/edumat/IHRIP/circle/modules/module18.htm.

125. This may describe some, but not all, indigenous conceptions of property. The famous quote " $[t]$ he Earth does not belong to man-man belongs to the Earth," is often cited as evidence of this indigenous view of land. Interestingly, this quote has been erroneously attributed to Chief Seattle. See, e.g., Snopes.com, Chief Seattle, http://www.snopes.com/quotes/seattle.html (last visited Jan. 16, 2006).

126. "[T]here is no such phenomenon as absolute private ownership of productive property in any known economic system." U.N. Comm'n on Human Rights [UNHCR], The Right of Everyone To Own Property Alone as Well as in Association with Others, 1479 , U.N. Doc. E/CN.4/194/19 (Nov. 25, 1993) (prepared by Luis Valencia Rodriguez).

The prototypical example of "inviolable and sacrosanct" private property rights, Roman law, also had property rights limitations that have not been properly appreciated in many analyses of Roman property law. Raul Manuel Somozo Alfaro, La Función Social de la Propiedad Agraria 11-15 (1980) (unpublished graduation thesis, University of Costa Rica School of Law) (on file with authors) (citing Floris Margadant, El pretendido absolutismo de la propiedad romana, 41 REVISTA FORO DE MÉXICO 3 (1956); L. Arisa Bustamante, De la propiedad privada a la propiedad comunitaria, 7 SeParata del ANuario de Derecho 12 (1967 Pan); E. Petit, Tratado ELEMENTAL DE DERECHO ROMANO 230 (José Fernandez Gonzalez trans.) (9th ed. 1966); JOAQUIN DE CAMPS Y ARBOIX, LA PROPIEDAD DE LA TIERRA Y SU FUNCIÓN SOCIAL 30 (1953); A. BRENES Cordoba, Tratoado de los bienes 24 (1963); M. Plañilo, Tratado elemental de derecho CIVIL 98 (José M. Cajica, Jr., trans.)(12th ed. 1955)).

127. BLACK'S LAW DiCTIONARY 83 (8th ed. 2004). The United Nations' Food and Agriculture Organization defined "allodial" without reference to taxes or eminent domain powers of the state and whether or not these are compatible with the concept of allodial tenure. U.N. FoOd \& AGric. ORG., Multilingual Thesaurus ON LAND TenURE 143 (2003). 
property rights movement in the United States; these people view allodial property as a means to reject any form of state control over property, including taxation and regulation. ${ }^{128}$

While some definitions of allodial indicate that land is only allodium if it is not subject to property taxes, ${ }^{129}$ this conflicts with the reality that land, in many of the states within the United States, is said to be allodial but still subject to property taxes. ${ }^{130}$ In practice, it would appear that little or no practical difference exists between allodial land and fee simple tenure in the United States, ${ }^{131}$ and this appears to be the case in most current "allodial" land systems.

Arrayed towards the "no-private-property" end of this broad continuum appear systems that contemplate monolithic ownership by a sovereign entity in which tenancies, estates, or usufruct rights are parceled out to varying extents. Communal, feudal, and regalía ${ }^{132}$ property systems fall in this category.

The regalia model involves the belief that all land originally belongs to the state, and thus only by a grant from the state can one hold a private

128. Means to Reduce the Debt and Allodial Title, http://www.angelfire.com/co4/ constcommittee/allodial_title.htm (last visited Mar. 4, 2006). For examples of some Web sites promoting allodial title, see, e.g., Speak Out.com, Tax Reform Forum, http://speakout.com/ forum_view.asp?Forum=Tax_Reform\&MID=22579\&mMID=22579 (last visited Mar. 5, 2006); Freedom Books Catalog Page, Protect Your Property from Unlawful Liens and Levies, http://www.livetaxfree.com/trueland.htm (last visited Mar. 5, 2006). In addition, many Web sites advertise services to help property owners in the United States secure "allodial" title to land. See, e.g., Inst. for Communications Res., Catalog for Allodial Titles and Patents, http://www. icresource.comoscommerce/product_info.php?products_id=50 (last visited Jan. 16, 2006); Tools for Freedom Catalog Page for Manual for the Freeman-Allodial and Patent Land Status, $\mathrm{http}: / / \mathrm{ww} w$.freedomprivacy.com/eliminate-reduce-taxes/allodial-land-patent.html (last visited Jan. 16, 2006); Law for the New Millenium, http://www.thepeoplesalternative.com/services.htm (last visited Jan. 16, 2006).

129. Means To Reduce the Debt and Allodial Title, http://www.angelfire.com/co4/ constcommittee/allodial_title.htm (last visited Mar. 5, 2006).

130. See, e.g., Charles F. Curry Co. v. Goodman, 737 P.2d 963, 965 (Okla. Civ. App. 1987) (finding without merit a contention of "allodial freehold" immunizing a property from foreclosure); County of Dane v. Every, 131 Wis. 2d 592 (Wis. App. 1986) (finding that the Wisconsin Constitution's declaration of all land in the state "allodial" does not eliminate the state's authority to impose property taxes); Dunn County v. Svee, 143 Wis. 2d 209 (Wisc. 1988).

131. See, e.g., BLACK's LAW DiCTIONARY 83 (8th ed. 2004) (defining allodial and allodium).

132. Regalia means "royal privilege," AMERICAN Heritage SPANISH DictionaRY (2000), $\mathrm{http}: / / \mathrm{mx}$.education.yahoo.com/reference/dict_en_es/ (last visited Jan. 16, 2006), or "a good of the Crown." See, e.g., OTS CAPDEQui, supra note 59, at 21 . The name was also given to a concession from the Crown. Michel J. Godreau \& Juan A. Guisti, Las Concesiones de la Corona y Propiedad de la Tierra en Puerto Rico, Siglos XVI-XX: Un Estudio Jurídico, 62 REV. JUR. U.P.R. 351, 407 (1993). The concept of regalia came from feudal times and stated that, upon conquest of an area by the Crown, all land belonged to the Crown. Jose Mencio Molintas, The Philippine Indigenous Peoples'Struggle for Land and Life: Challenging Legal Texts, 21 ARIZ. J. INT'L \& COMP. LAW 269, 290 (2004); see also OTS CAPDEQUí, supra note 59, at 21, 27. 
interest in land. ${ }^{133}$ The composición process the Spanish Crown attempted to use in the New World gave evidence of this conception of land since the process assumed that all land that had not been validly granted by the Crown still belonged to the Crown. ${ }^{134}$

The regalia concept of ownership developed out of Spanish feudal structures to resolve confusion about whether the king held land in the king's private role as the top rung of the feudal ladder or in the king's public role as the state sovereign. ${ }^{135}$ In Spain, the feudal system, known as señorio, arose due to the ineffectiveness of the state in administering justice. ${ }^{136}$ This led those that were unable to defend themselves to "recommend" themselves to a señor or lord. ${ }^{137}$ This recommendation included ownership of the land. ${ }^{138}$

As in the rest of Continental Europe's feudal system, there were many steps on the feudal ladder. In Spain, the top rung was the greatest lord or señor of all-the king-considered "owner" of all the land that had been recommended to all the inferior lords below him. The king was "owner" of all land, then, not because he was king, but because he was the ultimate señor in the feudal system. ${ }^{139}$ The king held this land personally and thus could even bequeath it to others at his death. However, with the reintroduction of the Roman law through the Institutes of Justinian in the second half of the twelfth century and first half of the thirteenth century, confusion arose regarding the king's ownership of this

133. See, e.g., German Fernandez del Castillo, La Propiedad y la Expropriación 33-35 (2d ed. 1987); Ralph LeE WoOdWARd, JR., CENTRAL AMERICA: A Nation Divided 55-56 (2d ed. 1985); $c f$. CIRCLE OF RIGHTS, supra note 124.

Interestingly, while the United States is seen as a prototypical example of the "propertyrights" model, the country from which the U.S. states fought for its independence, England, seemed conflicted on which model it followed in the Colonies. England sometimes advocated the "property-rights" model ideal that allowed settlers to claim land for themselves without an express grant from the state; on other occasions, the state insisted on the regalía model and ultimate ownership of all lands always resting in the Crown, thus leading to the requirement of an express grant to have a valid title claim. E.g., Kent McNeil, Self-Government and the Inalienability of Aboriginal Title, 47 MCGILL L.J. 473, 481-84 (2002); see also William Michael Treanor, The Origins and Original Significance of the Just Compensation Clause of the Fifth Amendment, 94 YALE L.J. 694, 697 (1985) (noting that English legal thought had notions of state rights to all land, thus allowing state limitations on private ownership rights).

Furthermore, even the United States has utilized the regalia concept of land in U.S. colonial endeavors. See, e.g., Jose Mencio Molintas, The Philippine Indigenous Peoples' Struggle for Land and Life: Challenging Legal Texts, 21 ARIz. J. INT'L \& COMP. LAW 269, 284 (2004).

134. See supra notes 83-90 and accompanying text; see also RALPH LEE WOODWARD, JR., CENTRAL AMERICA: A NATION DIVIDED 55-56 (2d ed. 1985).

135. OTs CAPDEQUi, supra note 59, at 19-22.

136. Id. at 20.

137. Id.

138. Id.

139. Id. 
land. ${ }^{140}$ Through a slow process of judicial development, lands held by the king became property of the king as head of the state rather than personal property of the king as the highest lord in the feudal structure, ${ }^{141}$ thus vesting title of the land in the state.

In Latin America, Mexico's revolutionary constitution expresses most directly and succinctly the regalía view of ownership. Article 27 declares that all land originally belongs to the state, which may pass title of land to individuals, thus creating private property. ${ }^{142}$ Similar language can be found in the constitutions of some states in the United States. ${ }^{143}$

Most modern nation-states fall within the broad middle of the property continuum, recognizing individual ownership of property even as they explicitly or implicitly retain the ultimate role of the state as the default owner of all property within their jurisdiction. ${ }^{144}$ Within this model, however, the extent to which property rights are individualized, and the extent to which the state may intervene in those rights, varies dramatically.

With the demise of feudalism, the Enlightenment saw emergence of an alternative view of the state and land ownership, grounded in the theory of natural law. This view, which arose largely in reaction against the arbitrary absolutism associated with feudalism, ${ }^{145}$ asserted that land

140. Id.

141. Id. at 21.

142. Constitucion Politica de los Estados Unidos MeXiCANOS art. 27 ("La propiedad de las tierras y aguas comprendidas dentro de los límites del territorio nacional, corresponde originariamente a la Nación, la cual ha tenido y tiene el derecho de transmitir el dominio de ellas a los particulares, constituyendo la propiedad privada." ["The land and waters within the national boundaries belong originally to the Nation, which has and continues to have the right to transmit ownership to individuals, thus constituting private property." (Thomas Ruppert trans.)]). The Constitution of Bolivia presents another example: "Las tierras son del dominio originario de la Nación y corresponde al Estado la distribución, reagrupamiento y redistribución de la propiedad agraria conforme a las necesidades económico-sociales y de desarrollo rural." ["Property is under the dominion of the Nation and the state holds the responsibility for distribution and redistribution of agricultural property according to socio-economic and rural development needs." (Thomas Ruppert trans.)]. CONST. OF BOLIVIA art. 165.

143. See, e.g., S.C. CONST. art. XIV, $\S 3$ ("The people of the State are declared to possess the ultimate property in and to all lands within the jurisdiction of the State; and all lands the title to which shall fail from defect of heirs shall revert or escheat to the people."); WISC. CONST. art. 9, $\S 3$ ("The people of the state, in their right of sovereignty, are declared to possess the ultimate property in and to all lands within the jurisdiction of the state; and all lands the title to which shall fail from a defect of heirs shall revert or escheat to the people."). (2004).

144. See Richard R. Powell \& Patrick J. Rohan, Powell on Real Property $§ 10.02$

145. Cf. Rafael Colina Garea, la Función Soclal de la Propiedad Privada en la CONSTITUCIÓN ESPAÑOLA DE 1978, at 30 (1997) (noting that the guarantees of individual rights against state action make sense in the context of the late eighteenth- and early nineteenth-century struggle against the plenary political power of nobles, lords, aristocracy, and ecclesiastic authorities); Somozo Alfaro, supra note 126, at 17, 23-24. 
ownership emerged independently of the state and that the state only exists because of a "social contract"146 and with the "consent of the governed.", 147

The English political philosopher John Locke is often credited with developing the modern "property rights" rationale that emphasized a natural law right to property. ${ }^{148}$ Locke theorized that property ownership arises from the individual's investment of sweat equity in property-the so-called "labor theory" of property. ${ }^{149}$ The state, in this view, was founded primarily to ratify and protect land rights acquired by natural law. ${ }^{150}$ In Europe, the natural law right to property was codified in article 17 of the 1789 French Declaration of the Rights of Man and of the Citizen, which provides, "Property, being an inviolable and sacred right, no one may be deprived of it; unless public necessity, legally investigated, clearly requires it, and just and prior compensation has been paid."151 This conception of private property cemented its dominance in western law with incorporation into the 1804 Napoleonic Code $^{152}$ and the United States Constitution. ${ }^{153}$ The civil codes of most Latin American countries originated primarily from the 1804 Napoleonic Code and echoed its view of private property. ${ }^{154}$

146. See, e.g., JoHn LOCKE, SECOND TREATISE ON CIVIL GovernMENT ch. VIII, $\S \S 95-97$ (1690); Jean Jacques Rousseau, The Social Contract OR Principles of Political Right 14 (1762).

147. "I moreover affirm, that all men are naturally in [the state of nature], and remain so, till by their own consents they make themselves members of some politic society." LOCKE, supra note 146 , ch. II, $\S 15$.

148. See id. ch. v.

149. Id. $\$ 27$. Jean Jacques Rousseau agreed that labor was a critical part of establishing property rights, at least in the absence of anyone with legal title. ROUSSEAU, supra note 146, bk. I, ch. 9.

150. "The great and chief end, therefore, of men's uniting into commonwealths, and putting themselves under government, is the preservation of their property. To which in the state of nature there are many things wanting." LOCKE, supra note 146, ch. IX, § 124.

151. Declaration of the Rights of Man and of the Citizen, art. 17, Aug. 26, 1789 (Xavier Hildegarde trans.), http://www.magnacartaplus.org/french-rights/1789.htm.

152. Colina GAREA, supra note 145, at 83; Somozo Alfaro, supra note 126, at 17. Section 544 of the French Civil Code reads: "Property is the right of enjoying and disposing of things in the most absolute manner, provided they are not used in a way prohibited by the laws or statutes." C. Crv. art. 544 (1804) (Fr.) available at http://www.napoleon-series.org/research/government/ code/book $2 /$ c_title02.html.

153. U.S. CONST. art. V.

154. Cf. MrRow, supra note 77 , at 97 (noting that in 1822 the French civil code was introduced as legislation in both Santander, Gran Colombia and Chile); id. at 98-99 (noting lessons Latin American leaders learned from the use of codes, especially that of Napoleon); $i d$. at 135 (noting the influence of the Napoleonic Code of 1804 on Haiti, the Dominican Republic, Bolivia, and other Latin American countries); id. at 137-38 (noting influence of Napoleonic Code on Bello's Code for Chile); Somozo Alfaro, supra note 126, at 17, 114. 
Thus, by the beginning of the twentieth century, Western legal thought had diminished the importance of feudal notions of sovereign ownership of private property. In civil law countries, property had become part of the corpus of what is known as "private law."15s In the civil law tradition, private law is found in the civil code, which, while dating back centuries, has its first comprehensive expression in the Napoleonic Code of $1804 .^{156}$ The Napoleonic Code codified the "inviolable" nature of the individual right to property expressed in the 1789 Declaration of the Rights of Man and of the Citizen and made it a matter of private civil law. ${ }^{157}$ The individual right to property thus entered the twentieth century on two formidable legal pillars: the liberal constitution and private civil law. ${ }^{158}$ Still, the long history of communal land in Latin America, pre-Colombian feudal tenure arrangements, the manipulation of land rights in Latin America by colonial powers, and extreme land concentration remained an integral part of Latin America.

\section{The Modern Social Function Doctrine}

Once the individualist notion of private property was enshrined in multiple civil codes, this liberal conception of property held the upper hand for almost 100 years. During the late nineteenth and early twentieth

155. See A.N. Yiannopoulos, L.A. Civil Law Treatise, Property $\S 4$ (4th ed. 2001).

156. See C. Civ. (1804) (Fr.).

157. See id.

158. The conception of private, individual property as an inviolable natural law right was not, even as far back as the eighteenth and nineteenth centuries, unchallenged by opponents. For example, the philosopher Jean Jacques Rousseau opined that all real property ultimately resided in the state since, as part of the social contract, each person delivered his or her person and goods to the state; the state then protects the rights of the possessors of property as depositories of the public good. See RouSSEAU, supra note 146, bk. 1, ch. 9. John Stuart Mill, in regard to property, said that "no exclusive right should be permitted in any individual, which cannot be shown to be productive of positive good." Edwin G. West, Property Rights in the History of Economic Thought, in PROPERTY RIGHTS 35 (2003) (quoting J.S. Mills). Mills and other utilitarian philosophers viewed property as something created and "permitted" by the state. Closer to home, Henry George during the late nineteenth and early twentieth century argued:

In the very nature of things, land cannot rightfully be made individual property.

This principle is absolute. The title of a peasant proprietor deserves no more respect than the title of a great territorial noble. No sovereign political power, no compact or agreement, even though consented to by the whole population of the globe, can give to an individual a valid title to the exclusive ownership of a square inch of soil. The earth is an entailed estate - entailed upon all the generations of the children of men, by a deed written in the constitution of Nature, a deed that no human proceedings can bar, and no proscription determine.

HeNRY GeORge, THE LAND QUESTION ch. VIII, at 45 (1884). George even said that "private property in land ... never arises from the natural perceptions of men, but springs historically from usurpation and robbery." Id. ch. IX, at 50. 
century; however, increasing inequality in property began to foment a reaction against the absolutist nature of property inherited from the French Declaration of the Rights of Man and of the Citizen as well as the 1804 Napoleonic Code. ${ }^{159}$ The reaction to this disparity and other manifestations of unbridled capitalism presented itself as the "socialization" of law. ${ }^{160}$ Auguste Comte, in 1850, planted the seed that would blossom into the modern social function. Comte wrote that all citizens act as public functionaries whose attributes determine their obligations and aspirations and that this concept should be expanded to include property. ${ }^{161}$

Most commentators ascribe the modern articulation of the Social Function Doctrine to the French jurist Leon Duguit. ${ }^{162}$ Writing in 1919, Duguit reasoned that the state's real authority emanates from the functions it performs; key among these functions is for the state to provide for certain social needs. ${ }^{163}$ In this context, state protection of private property remains justified only insofar as its protection by the state furthers the state obligation to ensure that property provides a "social function." 164 This view, and the fact that it gives the state the right to seize property for failure to effectively utilize the property for the benefit of society, fits comfortably with those property systems that offer greater opportunity for state intervention in property relations to achieve state ends. ${ }^{165}$ This view also fits comfortably within the historical context of the times, when socialism was on the march and the concept of "economic and social rights" gained currency. ${ }^{166}$ In Latin America, the

159. Many commentators have noted that the 1804 Napoleonic Code represented the pinnacle of individualism and protection of those with property while ignoring the needs of the larger society and those without property. See, e.g., Colina GAREA, supra note 145, at 168; Somozo Alfaro, supra note 126, at 5.

160. Somozo Alfaro, supra note 126, at 18-19.

161. Id. at 52.

162. See, e.g., David Schneiderman, Constitutional Approaches to Privatization: An Inquiry in the Magnitude of Neo-Liberal Constitutionalism, 63 LAW \& CONTEMP. PROBS. 83, 92 (2000); Sentencia C-204/01 § VII.16 (Supreme Constitutional Court of Colom. 2001).

163. See generally LeON DUGUT, LAW In THE MOdeRn STATE (1919).

164. Hendrix, supra note 124 , at 5 .

165. The concept of social function is not unique to Spain or Latin America. Germany has a similar concept in its constitution and Italy has the idea of social concept in its civil code. Id. at $5,8 \mathrm{n} .41$. In Indonesia, "social function" is rooted in the constitution and the belief that "[l] and is seen as the fundamental provider of food, shelter and clothing-rights that are guaranteed in the constitution and national philosophy." Craig C. Thorburn, The Plot Thickens: Land Administration and Policy in Post-New Order Indonesia, 45 ASIA PAC. VIEWPONT 33-49 (2004). Several other European nations and Japan also recognize the Social Function Doctrine.

166. See Charles A. Hale, The Civil Law Tradition and Constitutionalism in TwentiethCentury Mexico: The Legacy of Emilio Rabasa, 18 LAW \& HiST. REv. 257 (2000), available at $\mathrm{http} / /$ www.historycooperative.org/journals/lhr/18.2/hale.html. 
Mexican Revolution coincided with this era and its 1917 constitution, discussed below, represents the world's first example of what has been called "social constitutionalism.", 67 Following Mexico, other states in Europe and Latin America explicitly incorporated the Duguitian idea of social function in their constitutions. ${ }^{168}$

Despite the conventional dogma, Locke's labor theory of property and Duguit's notion of property's "social function" share a common attribute: neither condones allowing land appropriate for agricultural production to remain idle while willing laborers have no place to invest their labor. Nonetheless, as property theory has evolved in the twentieth century, Locke and Duguit have found themselves pushed to different ends of an increasingly muddled property spectrum. The echoes of these contrasting theories of ownership persist in increasingly subtle distinctions about the way that the state views the rights and obligations of property owners. These distinctions can be best illustrated by examining the use of state power to expropriate private property and the modern history of land reform in Latin America.

\section{Distinguishing the Common Law's "Public Use" Doctrine and Related Concepts in the Civil Law}

All states along the property rights continuum include policy justifications for limitations on property rights to benefit society, including the physical expropriation of property under appropriate circumstances. The substantive standard for expropriation in the United States requires that the expropriation be for a "public purpose."169 U.S.

While some might initially feel that the Social Function Doctrine represents the demise of private property or a "slippery slope" towards its destruction, many have advocated the Social Function Doctrine specifically as a way to protect private property from destruction. Among these count the Catholic Church; Somozo Alfaro, supra note 126, at 34, 39, 41; and Leon Duguit, id. at 55. In fact, the U.S.-led Alliance for Progress in the 1960s in Latin America actively promoted agrarian reform in Latin American countries as a way to deal with social inequalities that had great potential to spawn expanded communism in Latin America; domestic enabling legislation in many Latin American countries that enabled such U.S.-supported land reform to occur included the Social Function Doctrine as a foundational justification for the land reform. Somozo Alfaro, supra note 126 , at 85-88.

167. Diego Valadés, La No Aplicación de las Normas y el Estado de Derecho, 2 MEXICAN L. REv. 231 (2004), available at http:/www.juridicas.unam.mx/publica/librev/rev/boletin/ cont/103/art/art8.pdf.

168. These include Spain (1931); Weimar Republic (1919); Chile (1925), and Colombia (1936). See, e.g., Mario Verdugo Marinkovic, Emilio PfefFer Urquiaga \& alberto NAUdon del Río, ANÁlisis Constitucional del ProYecto ley Que Establece una Regalia MINERA AD-VALOREM Y CREA UN FONDO DE INNOVACIÓN PARA LA COMPETITIVIDAD § IV.a (2004), http://www.minmineria.cl/img/informeconstitucional.pdf.

169. U.S. CONST. amend. V. 
jurisprudence affords the state considerable leeway in applying this public purpose test. ${ }^{170}$ In Latin America, analogous terminology to "public purpose" can be found in all constitutions, and is most often characterized as "utilidad pública," or "public utility," an essentially direct translation of "public use."171 Other terms used to justify traditional expropriation may include "public interest" and sometimes includes "social interest," alth altho "social interest" may also be used to characterize something more akin to the Social Function Doctrine in some cases. The linguistic similarity of these standards is no coincidence. Latin American constitutions are largely modeled after their United States counterpart, ${ }^{173}$ especially in the area of individual rights. ${ }^{174}$ Included among these rights is the individual right to property and the corresponding governmental prerogative to expropriate for "utilidad pública."

Despite similar constitutional language to rationalize expropriation in countries adhering to both the common law and the civil law tradition, there remains a significant difference in the scope of expropriation in Latin America. The post-Enlightenment doctrinal gloss of social function marks the key difference. The United States, with its longstanding, Enlightenment-era liberal constitution, and its reluctance to revisit the 1789 text, has never had the opportunity to consider the inclusion of social and economic rights in its constitution. Europe, Latin America, and most other regions of the world, convulsed by war and

170. See, e.g., Haw. Hous. Auth. v. Midkiff, 467 U.S. 229, 241 (1984) (stating that "where [expropriation] is rationally related to a conceivable public purpose, the Court has never held a compensated taking to be proscribed by the Public Use Clause." A "public purpose" in U.S. jurisprudence regarding expropriations may include the government taking land from a private party for use by another private party as long as the primary motive behind the expropriation is the benefit to the public. See, e.g., Kelo v. City of New London, 843 A.2d 500, 522 (Conn. 2004) (noting that "public use" refers to the advantage gained by the public rather than strictly referring to public possession, use, or occupation and that economic development alone may serve as a sufficient "public purpose" as that term is used in the fifth amendment to the United States Constitution). Upon appeal of Kelo, the United States Supreme Court reaffirmed the broadest possible interpretation of "public use." Kelo v. City of New London, 125 S. Ct. 2655, 2669 (2005).

171. See, e.g., CONST. Of ARGENTINA art. 17; Const. of Bolivia art. 22; CONST. Of ChIle art. 19(24); CONST. OF COLOMBIA art. 58; CONST. OF COSTA RICA art. 45. The question of what qualifies as "public use" is very broad; this breadth may be part of the reason that few international claims have focused on this aspect of expropriations. RESTATEMENT (THIRD) OF FOREIGN RELATIONS LAW $\S 712 \mathrm{cmt}$. e (1987).

172. See, e.g., Const. Of Colombla art. 58; Const. of GuATEMala art. 40; Const. Of El SALVADOR art. 106.

173. Thomas T. Ankersen, Shared Knowledge, Shared Jurisprudence: Learning To Speak Environmental Law Creole (Criollo), 16 TUL. ENVTL. L.J. 807, 820-21 (2003).

174. See generally Albert P. Blautstein, The Influence of the United States Constitution Abroad, 12 OKLA. CITY L. REv. 435, 444-47 (1987). 
revolution in the twentieth century, have had ample opportunities to consider these so-called "second generation" rights and incorporate them into twentieth- century constitutions. The property rights provision of the constitution of the post-World War I German Weimar Republic succinctly captures this development, where, after guaranteeing the individual right to own property, the governmental right to expropriate property, and the governmental guarantee of indemnification for expropriated property, it characterizes property's social content. ${ }^{175}$

Article 153 of the ill-fated inter-World War Weimar Republic Constitution succinctly states, "Property obliges. Its use must serve the good of the community." 176 The constitution of Bolivia similarly includes both the utilidad pública standard for expropriation, and the social function obligation of productive use. ${ }^{177}$ This additional obligatory social good conception of property, distinct from and additional to the traditional public purpose (or utilidad pública) expropriation rationale, is qualitatively distinct from the liberal laissez-faire view of nonsocial function states like the United States. However, even in the United States, land concentration has resulted in involuntary land redistribution as a means to promote the public good. ${ }^{178}$ The following Part addresses the significance and historical necessity of the social function obligation in Latin America.

\section{B. Application of the Social Function Doctrine to Land Reform in Latin America}

In contrast to an expropriation standard that advances state interests when needed, the Social Function Doctrine actually imposes two related

175. See Colina GaREA, supra note 145 , at 45 .

176. See id.

177. CONSTITUCión PolítiCa DE LA RePúbliCa de Bolivia art. 7 states that "[t]oda persona tiene los siguientes derechos fundamentales, conforme a las leyes que reglamenten su ejercicio: ... i) A la propiedad privada, individual y colectivamente, siempre que cumpla una función social" ["Each person has the following fundamental rights according to the laws that regulate their exercise .... i) to private property, either individual or collective, as long as the property serves a social function."(Thomas Ruppert trans.)]. Article 22 further states that "[s]e garantiza la propiedad privada siempre que el uso que se haga de ella no sea perjudicial al interés colectivo. ... .II. La expropiación se impone por causa de utilidad pública o cuando la propiedad no cumple una función social." "“Private property is guaranteed as long as its use does not harm the collective interest .... II. Expropriation may occur for reasons of public utility or when property fails to serve a social function." (Thomas Ruppert trans.)]. The Bolivian Constitution is available online at University of Richmond, Constitution Finder, http://confinder.richmond.edu/ (last visited Mar. 5, 2006).

178. See, e.g., Haw. Hous. Auth. v. Midkiff, 467 U.S. 229 (1984) (upholding constitutionality of a Hawaii law that takes title from lessors and transfers it to lessees as a way to decrease severe land ownership concentration that was deemed detrimental to the public). 
sets of obligations. ${ }^{179}$ First, it imposes continuing, affirmative obligations on landowners to ensure that their property use serves a social function or risk expropriation. ${ }^{180}$ For example, echoing the early Weimar Republic expression of the social function, article 58 of the Constitution of Colombia provides that "[p]roperty is a social function which implies obligations.",181 Arguably, in the United States and other nonsocial function states, a property owner is under no affirmative, enforceable duty to ensure that her property fulfills some larger societal goal. In the United States, for example, it is presumed that the market assures this. Secondly, the Social Function Doctrine imposes a corresponding affirmative obligation on the state to expropriate land not fulfilling its social function. ${ }^{182}$ For example the Brazilian constitution provides that it is incumbent upon the Republic "to expropriate for social interest, for purposes of agrarian reform, rural property which is not performing its social function." ${ }^{\text {"183 }}$

By the middle of the twentieth century, the Social Function Doctrine had been explicitly incorporated into most of the constitutions of Latin America. ${ }^{184}$ Even those countries whose constitutions lack explicit reference to the term "social function," include language that leaves little doubt as to the Doctrine's existence, or at a minimum, incorporates it into agrarian reform legislation and general property law

179. See COlina GAREA, supra note 145 , at 148.

180. See id. at $148,150$.

181. CONSTITUCIÓN POLITICA DE COLOMBIA art. 58 ("La propiedad es una función social que implica obligaciones" [Property is a social function which implies obligations (Thomas Ruppert trans.)].

182. See Colina GaREA, supra note 145 , at 150 .

183. ConST. OF BRAZIL art. 184; cf. CONST. OF ColomBIA art. 64 ("Es deber del Estado promover el acceso progresivo a la propiedad de la tierra de los trabajadores agrarios, en forma individual o asociativa ... con el fin de mejorar el ingreso y calidad de vida de los campesinos." [It is an obligation of the State to promote progressive access to land for agricultural workers, either individually or in association... with the goal of improving the income and quality of life of the peasants." (Thomas Ruppert trans.)].

184. See, e.g., CONST. OF ARG. OF 1949 art. 38. (social function was subsequently eliminated in 1956 with the readoption of the 1853 constitution with reforms); CONST. OF BOLIVIA arts. $7.1,22,165$ (doctrine originally introduced in article 17 of the 1938 constitution); CONST. OF THE REPUBLIC OF BRAZIL art. 5(0)XXIII; CONST. OF ECUADOR art. 30 (added in article 183 of the 1946 constitution); CONST. OF CHLE art. 19(24); CONST. OF El SALVADOR art. 103 (added in article 137 of the 1950 constitution); CONST. OF THE REPUBLIC OF HONDURAS art. 103 (social function added in article 157 of the 1957 constitution); CONST. OF NICARAGUA art. 5 (added in article 65 of the 1939 constitution); CONST. OF PANAMÁ art. 45 (social function doctrine first added in 1947 constitution, article 47); CONST. OF SURINAME art. 34; CONST. OF VENEZUELA art. 115 (implicit) (including phrase "social function" explicitly in article 65 of the 1947 constitution but removing the phrase with adoption of the 1999 constitution). 
doctrine. ${ }^{185}$ As the twentieth century progressed, the familiar pattern of land concentration by elites progressed along with it. Reformers seized on property's social function to institute a new wave of agrarian reform aimed at breaking up persistent latifundios and alleviating landlessness. ${ }^{186}$

The 1917 Mexican Constitution and Duguit's idea of social function were born of the same social ferment, and Article 27 of the Mexican Constitution served as an inspiration in Europe: ${ }^{187}$

The Nation shall at all times have the right to impose on private property such limitations as the public interest may demand, as well as the right to regulate the utilization of natural resources which are susceptible of

185. Peru, Guatemala, Costa Rica, Venezuela, and Mexico lack explicit reference to the doctrine in their constitutions. Peru's 1979 constitution previously referred to property's social function. PALOMINO, supra note 44 , at 61 . The current Peruvian constitution does not explicitly impose positive obligations on property owners; owners only need utilize land in accordance with law. PERUVIAn CONST. OF 1993 art. 70. But see sources cited supra notes 291-295 (discussing current developments in Peru). Guatemala, which has some of the greatest land distribution inequity in the world, removed the phrase "social function" from its 1998 post civil war constitution, but continues to advocate the Doctrine in human rights sectors. Article 39 of the 1991 Constitution of Guatemala provides: "Se garantiza la propiedad privada como un derecho inherente a la persona humana, toda persona puede disponer libremente de sus bienes de acuerdo con la ley. El Estado garantiza el ejercicio de este derecho y deberá crear las condiciones que faciliten al propietario el uso y disfrute de sus bienes, de manera que se alcance el progreso individual y el desarrollo nacional en beneficio de todos los guatemaltecos." [Private property is guaranteed as an inherent right of the person, and every person may freely make use of such property within the confines of the law. The State guarantees the exercise of this right and should create conditions that facilitate the ability of property owners to use and enjoy their property in a manner that allows for individual growth and national development in the interest of all Guatemalans." (Thomas Ruppert trans.)].

[A]unque el término función social fue eliminado en el artículo 39 de nuestra Constitución de Derecho, ese término, y el concepto que abarca, está vigente en nuestra Legislación por encima de dicha norma constitucional. ["Although the term social function has been eliminated from article 39 of our constitution, this term and the concept it represents continue to be effective in our legislation." (Thomas Ruppert trans.)]

Pronunciamiento del Procurador Sobre el Derecho Humano a la Propiedad Privada 36 (1992).

Costa Rica also does not refer to "social function" in its constitution, but nonetheless explicitly added "social function" to its agrarian reform law. Ley de Tierras y Colonización, Law No. 2825, arts. 6, 21(i), 58, 150 (1962), available at http://www.racsa.co.cr/asamblea/ley/leyes_ nombre.htm. The president of Costa Rica rejected previous versions of the law with more references to social function, reasoning that rejection of the phrase "social function" in the constitution meant that the phrase in legislation contravened the constitution. Somozo Alfaro, supra note 126 , at 105-09.

186. See Ankersen, supra note 173 , at 809-10.

187. For example, it appears that the 1917 Mexican Constitution and its elaborate treatment of property influenced the 1931 Spanish Constitution. José Antonio Domínguez Luis, Sobre la Funcionalización del Derecho de Propiedad, 5 REVISTA JURIDICA DE LA COMUNIDAD DE MADRID(1999), available at http://www.madrid.org/comun/rev_juridica/0,3848,110064989_ 110071652_127535973_12127029_12123908,00.html. 
appropriation, in order to conserve them and to ensure a more equitable distribution of public wealth. With this end in view, necessary measures shall be taken to divide up large landed estates; to develop small landed holdings in operation; to create new agricultural centers, with necessary lands and waters; to encourage agriculture in general and to prevent the destruction of natural resources, and to protect property from damage to the detriment of society. Centers of population which at present either have no lands or water or which do not possess them in sufficient quantities for the needs of their inhabitants, shall be entitled to grants thereof, which shall be taken from adjacent properties, the rights of small landed holdings in operation being respected at all times. ${ }^{188}$

Article 27 further provides: "The federal and state laws, within their respective jurisdictions, shall determine in what cases the occupation of private property shall be considered to be of public utility; and in accordance with such laws, the administrative authorities shall issue the respective declaration."189 This would appear to constitute a reversal of the presumption of laissez-faire deference to private property in favor of a proactive state role in determining the status of property visà-vis its contribution to social welfare.

Although the 1917 Mexican Constitution did not use the phrase "social function," the concept is clearly implicit. ${ }^{190}$ Duguit's doctrine has been specifically incorporated into subsequent legislation and has found a place in Mexican legal doctrine and jurisprudence as well. A 1928 revision to the Mexican civil code described property "as a social function and not a subjective right." The 1928 code's characterization of property under the civil law as no longer subjective represents a dramatic departure from its treatment under the 1804 Napoleonic Code as a matter of private or "subjective" law, bringing it into the realm of "objective" or public law, ${ }^{191}$ substantially undermining the second of the two pillars of property's liberal era doctrinal foundation. ${ }^{192}$ A Mexican agrarian court put it bluntly when it concluded that the grammatical, historical, logical, and systematic interpretation of article 27 requires the conclusion that the right to property in Mexico has been restricted and subjected to the

188. Constitución Politica de los Estados Unidos MeXiCANOS art. 27, available at http://www.ilstu.edu/class/hist263/docs/1917 const.html.

189. Id.

190. Somozo Alfaro, supra note 126, at 80 . It is hardly surprising that the 1917 Mexican Constitution did not use the phrase "social function" since it was not until two years later, in 1919, did Leon Duguit use the term in his writing. DugurT, supra note 163.

191. See John Henry Merryman, The Public Law-Private Law Distinction in European and U.S. Law, 17 J. OF PUB. LAW 1 (1968), for more information on the distinction between public and private law.

192. See id. 
public interest. ${ }^{193}$ In addition to court rulings referring to the social function inherent in article 27 of the Mexican Constitution, later Mexican law refers to the social function of land. ${ }^{194}$

Like most of Latin America, Brazilian colonial history resulted in large latifundios. ${ }^{195}$ In contemporary Brazil about one percent of the population in Brazil owns approximately forty-six percent of the land. ${ }^{196}$ The phrase social function first appeared in Brazilian law in the constitution of 1946 , but was largely ignored by the government until the end of military government in Brazil in $1985 .{ }^{197}$ In 1988 Brazil adopted a far-reaching new constitution that made the state responsible for expropriating rural land not serving its social function. ${ }^{198}$ The new constitution includes seven explicit references to the social function of property. ${ }^{199}$ Brazilian law considers that rural land serves a "social function" where " $80 \%$ of the surface is completely and effectively utilized; where appropriate use is made of the natural resources, ecological and labor standards are respected, and the use is considered to be of common benefit to land owners and wokers."200 Interestingly, the 1988 Brazilian Constitution also requires urbanized land to conform to its social function, and authorizes expropriation when urban land is not used in conformance with constitutionally-mandated master plans for metropolitan areas. ${ }^{201}$ Brazil's new constitution, as well as procedural forms that streamline judicial action, coincided with the emergence of an organized squatter movement called the Movimento dos Trabalhadores Rurais Sem Terra, or MST. ${ }^{202}$ The MST is aggressively pursuing

193. Sentencia 523/96 (juicio agrario, Mexico, published in the Diario Oficial de la Federación, June 16, 1998) (sixth section under heading "Considerando"). In this case, land was adjudged not in fulfillment of its social function since the owner planted cannabis sativa (marihuana) on the land. Id. For cases presenting a similar scenario, see also Sentencia 489/96 (juicio agrario, Mexico, published in the Diario Oficial de la Federación, June 9, 1998); sentencia 525/97 (juicio agrario, Mexico, published in the Diario Oficial de la Federacion, Jan. 11, 1999).

194. See, e.g., Ley de Desarrollo Urbano del Distrito Federal, arts. 2.II, 6 (Feb. 7, 1996).

195. Kevin E. Colby, Brazil and the MST: Land Reform and Human Rights, 16 N.Y. INT'L L. REV. 1, 10-11 (2003).

196. Id. at 1,3 .

197. Id. at 11-12.

198. CONST. OF BRAZIL art. 184(0), available at http://www.oefre.unibe.ch/law/icl br00000_.html.

199. Id. arts. 5(0)XXIII, 156(1), 170(0)III, 182(2), 184(0), 185(1), 186.

200. Org. Of Am. States, Inter-American Comm'n on Human Rights, Report on the Situation of Human Rights in Brazil, ch. VII, A, http://www.cidh.oas.org/countryrep/brazil-eng/ Chaper\%207\%20.htm.

201. CONST. OF BRAZIL art. 182(2).

202. See generally PETER P. Houtzager, SOClal Function of PROPERTY, MOVEMENT OF THE LANDLESS (MST), AND THE JUDICIAL FIELD IN BRAZIL (2003), http://www.ids.ac.uk/ids/law/ pdfs/socialfunction.pdf. 
organized land invasions of large landholdings while defending these claims in courts on the basis of the Social Function Doctrine. ${ }^{203}$

Colombia remains a regional leader in land concentration, ${ }^{204}$ largely the result of the initial distribution of land during colonization. ${ }^{205}$ Colombia first attempted land reform in 1936 but largely failed. ${ }^{206}$ In 1961, Colombia formed the National Institute for Agrarian Reform and Frontier Settlement, and by the end of the decade, land reform seemed poised to take off; however, a revolt by landowners effectively scuttled this effort by 1972. ${ }^{207}$ Those familiar with Colombia assert that land distribution in Colombia has not progressed since $1972 .^{208}$ In 1994, Colombia passed Law 160, designed to realize the State's obligation to promote access to land. ${ }^{209}$ This latest effort has apparently done little to improve the overall impact of land reform, ${ }^{210}$ undoubtedly hampered by the country's problematic low-grade civil war. Despite limited success in application, however, Colombia does not want for doctrine or jurisprudence when it comes to social function.

The phrase "social function" first appeared in the Colombian constitution in $1936^{211}$ and has remained a staple of Colombian property law. The Social Function Doctrine in article 58 of the current Colombian constitution follows the positive obligation approach to social function. ${ }^{212}$ This obligation requires the use of land for the benefit of the community and not just for the "exclusive and egotistical personal benefit of the property owner," as the Colombian Supreme Constitutional Court has characterized it. ${ }^{213}$ The Constitutional Court has further stated that the Social Function Doctrine

203. Id.

204. D.M. Grusczynski \& C. Felipe Jaramillo, Integrating Land Issues into the Broader Development Agenda: Colombia, in LAND REFORM, LAND SETTLEMENT AND COOPERATIVES 75 (2003), available at ftp://ftp.fao.org/docrep/fao/006/y5026E/y5026e01.pdf.

205. Id. at 76 .

206. Klaus Deininger, Land Policies for Growth and Poverty Reduction 147 (2003).

207. Grusczynski \& Jaramillo, supra note 204, at 82.

208. See, e.g., id.

209. Law 160, 1994, art. 1 (Colombia), available at http://www.incora.gov.co/capitulol. htm.

210. DEININGER, supra note 206, at 147; Grusczynski \& Jaramillo, supra note 204, at 82.

211. Sentencias C-223/94 § IV.; C-389/94; C-204/01 §VII.17; T-427/98 § III.C.3; C157/97 § VI.2.A (Supreme Constitutional Court of Colombia).

212. CONST. OF COLOMBIA art. 58; Sentencia C-223/94 § IV (Supreme Constitutional Court of Colombia).

213. Sentencia C-223/94 § IV (Supreme Constitutional Court of Colombia)(Thomas Ruppert trans.); see also Sentencias C-595/95 § VI.h, T-427/98 § III.C.3 (Supreme Constitutional Court of Colombia). 
signifies a great advance in western thought related to two antagonistic positions that find their conciliation in the social function: individualism and collectivism. The former negates, or at least minimizes, the social and public character of the right to property; at the same time, the latter rejects or diminishes the private and individual character that the right to property may have. The doctrine of the social function of property establishes that the right to property is simultaneously individual and social. ${ }^{214}$

The Social Function Doctrine of the Colombian Constitution imposes the positive obligation of an owner to "use property not only in a way that does not prejudice the community but that is beneficial to the community."215 Failure of land to fulfill its social function can result in expropriation, and at one point even the more drastic remedy of uncompensated forfeiture was contemplated. ${ }^{216}$ Prior Colombian law distinguished forfeiture of land for failure to fulfill social function from ordinary expropriation under the public utility doctrine, and held that compensation would not be required for social function forfeitures. ${ }^{217}$ However, in 1999, the legislature of Colombia passed a law forbidding expropriation of land without paying compensation. ${ }^{218}$ This law eliminated the paragraph in the constitution that allowed the legislature to establish cases in which, due to considerations of equity, indemnification would not be required to expropriate land. Even so, the Supreme Constitutional Court of Colombia has continued to emphasize how different the 1936 and 1991 Constitutions treated property when compared with the liberal-era 1886 Constitution. ${ }^{219}$ The court used these differences to justify reforming the 1887 Colombian Civil Code, which allowed for the "arbitrary" disposition of property. ${ }^{220}$ The court found the use of the term "arbitrary" in conflict with property's social function and ordered it stricken. ${ }^{221}$

214. Sentencia C-238/97 §VI.3 (Supreme Constitutional Court of Colombia) (Thomas Ruppert trans.); see also Sentencia C-428/94 §VII.4 (Supreme Constitutional Court of Colombia).

215. Sentencia C-389/94 § VII.2 (Supreme Constitutional Court of Colombia)(Thomas Ruppert trans.); see also Sentencia C-595/95 § VI.h (Supreme Constitutional Court of Colombia).

216. Sentencia C-389/94 § VII.3 (Supreme Constitutional Court of Colombia).

217. Id. While forfeiture of land may occur when ownership is a result of illegal activities or enrichment, $i d$., forfeiture for failure to fulfill the social function is much broader than penal offenses leading to forfeiture. See, e.g., Sentencia C-409/97 §VI.2 (Supreme Constitutional Court of Colombia). 1999).

218. Acto Legislativo 01, 1999, Diario Oficial, año CXXXV. N. 43654, page 49 (Aug. 4,

219. Sentencia C-595/99 § VI.B.2 (Supreme Constitutional Court of Colombia).

220. Id. §VI.B.2, VI.C.

221. Id. 
Venezuela, with its recently elected populist government under the leadership of Hugo Chávez, presents an interesting case. In Venezuela, sixty percent of the arable land belongs to two percent of the population, making land reform a high priority of the Chávez government. ${ }^{222}$ In 1999, Chávez supported a new constitution for the country. ${ }^{223}$ Up until that point, the constitution in effect since 1961 had explicitly included a provision concerning the social function of property. ${ }^{224}$ The new constitution eliminated the phrase "social function," and instead created an expropriation standard based on "public utility or social interest.",225 In the absence of the public record that evidences the rationale for this change, it would appear that the Social Function Doctrine is alive and well in Venezuela, perhaps embedded in the associated phrase "social interest." Evidence of this appears in a 2001 presidential decree specifying that private lands are "subject to the social function of providing for the agro-alimentary security of the country."226 When he signed the decree into law, Chávez said that "the war against latifundios is key to the revolution.",227 The decree gives squatters the right to stay on land that they occupied as idle land until the state can expropriate the land. ${ }^{228}$ The decree also gives any citizen the right to report idle or

222. Martin Edwin Andersen, Freedom House, Countries at the Crossroads: COUNTRY PROFILE OF VENEZUELA 9 (2004), available at http:/unpanl.un.org/intradoccgi/idc_cgi_isapi.dll?IdcService=DOC_INFO\&dID=18039.

223. See id. at 1.

224. 1961 CONST. OF VENEZUELA art. 99, available at http://www.cervantesvirtual.com/ servlet/SirveObras/00361841222258395209079/index.htm. The 1961 constitution provided:

The right to property is guaranteed. In virtue of its social function, property will be subjected to the contributions, restrictions, and obligations established by laws designed to further public utility and the general interest. [Se garantiza el derecho de propiedad. En virtud de su función social la propiedad estará sometida a las contribuciones, restricciones y obligaciones que establezca la ley con fines de utilidad pública o de interés general.].

225. The 1999 Venezuelan constitution states that "[p]roperty will be subjected to the contributions, restrictions and obligations established by law to promote public utility or the general interest. Only for public utility or social interest, determined by a court judgment and timely payment of just compensation, may any type of property be expropriated." CONST. OF VENEZUELA art. 115.

226. Presidential Decree No. 1546, Official Gazette of the Bolivarian Republic of Venezuela, No. 37,323, art. 2(5) (Nov. 9, 2001) (Thomas Ruppert trans.), available at http://www. gobiernoenlinea.gob.ve/docMgr/sharedfiles/294.pdf; see also id. art. 18 (referring to the social function of land).

227. Sibylla Brodzinsky in Hato el Chacote, Squatters Sit Tight as Land Revolution Is Put to the Test in Venezuela, THE GUARDIAN (U.K.), Jan. 25, 2005, available at http://www.guardian. co.uk/venesuela/story/0,12716,1397833,00.html.

228. Presidential Decree No. 1546, Official Gazette of the Bolivian Republic of Venezuela, No. 37. 323, art. 2(5). 
uncultivated land to the government. ${ }^{229}$ Idle land is defined as land that fails to produce at least eighty percent of its appropriate agricultural output. $^{230}$

For historical and geographical reasons, Costa Rica's relatively egalitarian land distribution pattern stands out when compared to the rest of the region. ${ }^{231}$ Even so, it did not escape the doctrinal influences of social constitutionalism, including the social function of property. The current constitution of Costa Rica, among the region's oldest (1949), also lacks explicit reference to social function. However, the 1964 Land and Colonization Law provides that "expropriation will be realized in the first place over those lands that do not comply with their social function." 232 The statute goes on to describe instances where social function is not met and the state may order expropriation. ${ }^{233}$ Possibly affected lands include certain unimproved lands, lands acquired for speculation and subdivision that have not subsequently been developed or whose development does not comply with pertinent laws, and agricultural lands used for cattle ranching (e.g., haciendas). ${ }^{234}$ A separate provision authorizes anyone to denounce lands that do not conform to the social function, creating a third-party right to induce expropriation. ${ }^{235}$

This brief review of the Social Function Doctrine in selected Latin American nations demonstrates that the doctrine and its historical necessity as a means to address land concentration are alive and well in the region. The doctrine would appear to have weathered a trend toward neoliberal governance in Latin America, and found new life in recently elected populist governments in Brazil, Bolivia, and Venezuela. Moreover, the emergence of independent judiciaries and their recorded jurisprudence has provided an opportunity to explore more fully its application, and gain greater insight into the extent to which it is deeply rooted in legal doctrine and political philosophy in the region. At the same time, in Latin America the notion of property's social function is inextricably tied to agrarian reform, an imperative which has diminished in some countries in the region.

229. Id. art. 37.

230. Id. arts. 106-107.

231. See Hector Perez-Brignoli, a Brief History of Central america 99, 121 (Ricardo B. Sawrey A. \& Susana Stettri de Sawrey trans., 1989).

232. Ley de Tierras y Colonización, Law No. 2825, published in Alcance $N^{\circ} 90$, de la Gaceta $N^{\circ} 278$, de 8 de diciembre de 1962 (Costa Rica) )(Thomas Ruppert trans.). The law also protects small agricultural plots from any sort of expropriation if they currently fulfill their social function. Id. art. 142.

233. Id. art. 144.

234. See id.

235. Id. art. 6 . 


\section{RECENT DEVELOPMENTS AND CHALLENGES TO THE SOCIAL FUNCTION DOCTRINE}

Throughout the twentieth century, the Social Function Doctrine has served, both explicitly and implicitly, as the juridical basis to justify drastic measures to restructure land policy in Latin America through agrarian reform. At the same time the Doctrine has served as an engine of development policy, used to settle the "tierras baldias," the vast, forested "wasteland," which policy makers viewed as safety valves in which to release the growing masses of landless peasants marching to the urban megacities of the region. ${ }^{237}$ The confluence of human rights and environmental concerns in the 1980s and 1990s challenged these policies. At the same time, the growing impetus toward a hemispheric free trade agreement and the neoliberal "commoditization" of property continues to challenge social notions of property. Here we explore some contemporary developments in the Social Function Doctrine and its current application to land policy.

\section{A. The International Human Rights Dimension of the Social Function Doctrine}

The eighteenth-century liberal constitutional right to be free from arbitrary state interference with an individual's property did not impose positive obligations on the state to provide individuals with land, or on individuals to ensure that their land was used for productive purposes. In the liberal constitutional model, the market takes care of land redistribution and ensures its productivity. In contrast, the social constitutional model obliges property owners to utilize property productively and for socially beneficial purposes, and obliges the state to ensure that this occurs. This positive duty of the state to intervene in private property relations to ensure its social function fits within the paradigm of what human rights scholars call "second generation rights." ${ }^{238}$ Second generation rights are generally considered to be social

236. Cf., e.g., Schneiderman, supra note 162, at 93 (noting that Colombia used "social function" as a justification for settling "seemingly empty and unproductive lands").

237. See generally H. JEFFrey LeONARD, NATURAL RESOURCES AND ECONOMIC DEVELOPMENT IN CENTRAL AMERICA (1987).

238. An essential difference between first- and second-generation rights is that second generation (i.e., social and economic rights) rights require states to take affirmative, active steps to promote and secure these rights since state inaction is insufficient. See, e.g., Marc Bossuyt, International Human Rights Systems: Strengths and Weaknesses, in HUMAN RIGHTS IN THE Twenty-First Century: A Global Challenge 52 (Kathleen E. Mahoney \& Paul Mahoney eds., 1992) (noting that civil rights primarily require state abstention from action whereas social rights require active intervention from the State). First generation rights are most often thought of 
and economic rights, rights inuring to the benefit of all society that the state is obliged to promote. ${ }^{239}$

The difference between the "right to property" in liberal propertyrights systems such as the United States ${ }^{240}$ and the social function of property in the social constitutional systems of some European and most Latin American countries can be seen in two key twentieth-century international human rights accords: the International Covenant on Civil and Political Rights (ICCPR) ${ }^{241}$ and the International Covenant on Economic, Social, and Cultural Rights (ICESC). ${ }^{242}$ The United Nations charter envisioned a single declaration of general human rights principles followed by a single convention on their implementation. ${ }^{243}$ While the United Nations Universal Declaration on Human Rights ${ }^{244}$ enjoyed broad international support, ${ }^{245}$ a split occurred among the world's nation-states regarding a covenant for implementation of the Declaration. ${ }^{246}$ Many developed nations, led by the United States, wanted a "negative rights" document, analogous to the United States Bill of Rights, which grants

as limitations on state action to ensure individual rights. According to one well-known Costa Rican jurist, the difference between the classic, first generation right to property and its second generation expression may present itself more clearly in Spanish than it does in English. In Spanish, the first-generation right is best expressed as "derecho de propiedad" whereas in the American Declaration, the second-generation right is expressed as the "derecho a la propiedad." See, e.g., RICARDo Zeledón ZELEDón, DERECHO AGRARIO Y DERECHOS HuMANOS 30 (2002). At the same time, others assert that the distinctions between first and second generation human rights are blurring. Richard H. Stanley, Remarks Presented at the Thirty-Eighth Strategy for Peace Conference (Oct. 23, 1997) (transcript available at http://www.stanleyfoundation.org/ reports/SPC97A.pdf).

However, many assert that to divide first and second generation rights between those that are "negative" versus "positive" fails to take account of the fact that some first generation rights (such as that to a speedy trial) require a substantial positive investment on the part of the state whereas some second generation rights (such as the right to unionize) require little expenditure on the part of the state. MARY DOWELL-JONES, CONTEXTUALISING THE INTERNATIONAL COVENANT ON ECONOMIC, SOCIAL AND CULTURAL RIGHTS: ASSESSING THE ECONOMIC DEFICIT 4 (2004).

239. See The Center for International Environmental Law, Human Rights, Er:vironment, and Economic Development: Existing and Emerging Standards in International Law and Global Society, http://www.ciel.org/Publications/olp3v.html (last visited Mar. 5, 2006).

240. The United States is often held up as an example of the state most protective of private property rights. Cf. van der Vyver, supra note 5, at 125-26.

241. Dec. 16, 1966, 999 U.N.T.S. 171, 6 I.L.M. 368 (1967); G.A. Res. 2200, 21 GAOR, Supp. No. 16, at 52, U.N. Doc. A/6316) (1976).

242. Dec. 16, 1966, 993 U.N.T.S. 3, 6 I.L.M. 360 (1967) (Annex to G.A. Res. 2200, 21 GAOR, Supp. No. 16, at 490, U.N. Doc. A/6316 (1976)).

243. F. Pocar, Codification of Human Rights Law by the United Nations, in PERSPECTIVES ON INTERNATIONAL LAW 140-41 (Nandasiri Jasentuliyana ed., 1995); $c f$. KIRSTEN SELLARS, THE RISE AND RISE OF HUMAN RIGHTS 76 (2002).

244. Universal Declaration of Human Rights, G.A. Res. 217A(III), at 71 (Dec. 10, 1948).

245. SELLARS, supra note 243, at 21, 23.

246. Id. at $23,74,79$. 
rights to be free from government interference. ${ }^{247}$ Developing states, however, were more concerned about positive social rights that require the government to affirmatively provide certain rights or goods to the people. ${ }^{248}$ What eventually emerged were two separate human rights documents. ${ }^{249}$ In fact, the United Nations, in an effort to secure broad support, specifically avoided the controversial topic of property in both of these global covenants. ${ }^{250}$

The American Convention on Human Rights, the binding human rights charter for most of the states in the Western Hemisphere, would appear to encompass both the individual and the social aspect of the right to property. Article 21 provides that " $[\mathrm{e}]$ veryone has the right to the use and enjoyment of his property. The law may subordinate such use and enjoyment to the interest of society.,251 Other regional human rights agreements also use similar language. ${ }^{252}$

Another source of emerging international law on the Social Function Doctrine comes from the European Court of Justice (ECJ), which has held that, by virtue of its inclusion in the constitutions of most

247. See J. SCOTt DAVIDSON, HUMAN RightS 6 (1993) (noting that American, French, and English revolutions primarily focused on "right to be free from" rather than the "right to").

248. Asbjorn Eide, Strategies for the Realization of the Right to Food, in HuMAN Rights IN THE TWENTY-FIRST CENTURY: A Global Challenge, supra note 238, at 460-61. This split again showed itself in 1974 when the United Nations General Assembly voted on the Charter of Economic Rights and Duties of States. RESTATEMENT (THIRD) OF FOREIGN RELATIONS LAW $\S 712$, reporter's note 1 (1987). This allowed that states have the right "to nationalize, expropriate or transfer ownership of foreign property." Id. The United States and five other developed states voted against the Charter while one hundred-twenty, mostly developing nations, voted in favor. Id.

249. SELLARS, supra note 243, at 79.

250. van der Vyver, supra note 5, at 129.

251. Organization of American States, American Convention on Human Rights, Nov. 22, 1969, O.A.S.T.S. No. 36, 1144 U.N.T.S. 123 (entered into force July 18, 1978). The United States has signed but not ratified the American Convention on Human Rights. It has signed and ratified the American Declaration of Human Rights which provides that "[e]very person has a right to own such private property as meets the essential needs of decent living and helps to maintain the dignity of the individual and of the home." American Declaration of the Rights and Duties of Man, art. XXIII, OEA/ser. L./ V./II.23, doc. 21, rev. 6 (1948) [hereinafter American Declaration]. This Declaration was approved in 1948 at the 9th International American Conference in Bogotá, Colombia.

252. 1952 Protocol to the 1950 European Convention on Human Rights, http://www.hri. org/docs/ECHR50.html ("Every natural or legal person is entitled to the peaceful enjoyment of his possessions.... The preceding provisions shall not, however, in any way impair the right of a State to enforce such laws as it deems necessary to control the use of property in accordance with the general interest." (emphasis added)). Article 14 of the African Charter on Human and Peoples' Rights reads: "The right to property shall be guaranteed. It may only be encroached upon in the interest of public need or in the general interest of the community and in accordance with the provisions of appropriate laws." African [Banjul] Charter on Human and Peoples' Rights, OAU Doc. CAB/LEG/67/3 rev. 5, 21 I.L.M. 58 (1982), adopted June 27, 1981, entered into force Oct. 21, 1986, http://wwwl lumn.edu/humanrts/instree/zlafchar.htm (emphasis added). 
of the member states of the European Union, the Social Function Doctrine represents binding European law. ${ }^{253}$ In the ECJ and its member countries the doctrine appears to have been used primarily to justify state regulation of property in the face of claims relating to the infringement of the right to property under European Community law. ${ }^{254}$ In this sense it appears more analogous to the public health, safety and welfare police power basis for regulation in the United States. ${ }^{255}$ This is a markedly different application of the doctrine than the positive obligation it imposes on landowners in Latin America to productively use their property to benefit society. By the time the Social Function Doctrine had found its way into European legal thought, the urgency for land reform felt in Roman times had diminished whereas in Latin America the two impulses converged.

\section{B. Accommodating "Sustainable Development": Ecological Possession and the "Socio-Environmental Function" of Land}

As the Social Function Doctrine was incorporated into the constitutions, civil codes, and agrarian reform statutes of Latin American countries, there arose a need to determine when property served its social function. Typically a landowner demonstrated social function through "productive use," which in an agrarian sense meant clearing and cultivating land. $^{256}$ If a property owner allowed arable land to remain fallow, the landowner risked not only invasions by squatters, but expropriation under the Social Function Doctrine. ${ }^{257}$ In contemporary Latin America, this led rational landowners to seek to clear their land in order to ensure possession, demonstrate ownership by fencing and acquiring cattle and then seeking title. ${ }^{258}$ An unintended consequence of this development policy founded on social function has been massive

253. Case 44/79, Liselotte Hauer v. Land Rheinland-Pfalz, 1979 E.C.R. 3727.

254. Id. paras. 18-19; see also The Queen v. Sec'y of State for the Env't, No. C-293/97, para. 54, available at http:www.eel.nl (finding that the right to property must be viewed in relation to property's social function in this decision upholding regulation of nitrates); Schrader v Hauptzollamt Gronau, [1989] ECR 2237, para. 15; Case C-280/93 Germany v. Council [1994] ECR I-4973, para. 78.

255. See, e.g., Village of Euclid, Ohio v. Ambler Realty Co., 272 U.S. 365, 395 (1926).

256. COLINA GAREA, supra note 145, at 152 (citing several Spanish laws imposing the cultivation obligation on agricultural property owners, dating back to the Franco regime). Colina Garea also cites a number of other Spanish and Italian commentators for this proposition.

257. See, e.g., supra Part III.B.

258. See, e.g., Ankersen, supra note 173, at 810 (citing Marianne Schmink, The Rationality of Tropical Rainforest Destruction, in MANAGEMENT OF FORESTS IN TROPICAL AMERICA: PROSPECTS AND TECHNOLOGIES 11, 11-30 (Julio C. Figueroa Colón et al. eds., 1987)); Philip M. Fearnside, Land-Tenure Issues as Factors in Envtl Destruction in Brazilian Amazonia: The Case of Southern Pará, 29 WoRLD DEV. 1361, 1368-69 (2001). 
deforestation of some of the last remaining tropical forests in the region. ${ }^{259}$ Thus, "productive use" to demonstrate "possession" included the creation of massive cattle ranches on forested frontiers. ${ }^{260}$ This perverse policy compounded the problem of land concentration in the region, contributed to conflicts in the region with "unproductive" occupants such as indigenous peoples and traditional societies, and resulted in alarming rates of deforestation in some countries. ${ }^{261}$

As the nations of Latin America began to realize the consequences of settlement on the agricultural frontier, efforts were taken to redefine "social function" in a manner that accommodates, among other state interests, the "ecological function" of property. Colombia, ${ }^{262} \mathrm{Chile}^{263}$ Costa Rica, ${ }^{264}$ Mexico, ${ }^{265}$ and Brazil have all altered their interpretation of social function to accommodate the ecological function of land. As a result, one can demonstrate "possession" and "productive use," and hence-social function - through the conservation of land, as well as its cultivation. ${ }^{266}$

This postmodern development, the ecological function of property, also now serves to justify environmental and land use controls to protect the environment in a manner similar to social function's use in Europe. For example, in 1994, the Colombian Supreme Constitutional Court applied the Social Function Doctrine to forbid a land use that contaminated an otherwise clean source of municipal drinking water. ${ }^{267}$

259. See Fearnside, supra note 258, at 1369.

260. See id. at 1362.

261. See, e.g., Marianne Schmink \& Charles WoOd, Contested Frontiers in AMAZONIA (1992).

262. CONST. OF COlOMBIA art. 58 ("La propiedad es una función social que implica obligaciones. Como tal, le es inherente una función ecológica." ["Property has a social function which implies obligations. As such, land has an inherent ecological function." (Thomas Ruppert trans.)]); Colombian Law 388 of 1997, arts. 2(1), 3(2) (July 18, 1997).

263. CONST. OF CHILE art. 19(24) ("Sólo la ley puede establecer el modo de adquirir la propiedad, de usar, gozar y disponer de ella y las limitaciones y obligaciones que derive $\mathrm{n}$ de su función social. Esta comprende cuanto exijan los intereses generales de la Nación, la seguridad nacional, la utilidad y la salubridad públicas y la conservación del patrimonio ambiental." ["Only the law may establish the modes of acquiring, using, enjoying, and disposing of property as well as the limits and obligations that derive from property's social function. This includes requirements to serve the general interests of the Nation, national security, public utility and health, and conservation of the nation's environmental patrimony." (Thomas Ruppert trans.)]).

264. Ankersen, supra note 173, at 811-12.

265. See ENVTL. LAW InST. ET AL., LEGAL TOOLS AND INCENTIVES fOR PRIVATE LANDS CONSERVATION IN LATIN AMERICA: BUILDING MODELS FOR SuCCESS 144 (2003), available at http://www.elistore.org/books_detail.asp?ID=10916 ("Mexican law no longer threatens the expropriation of land if adequate social 'use' is not made.").

266. See, e.g., Ankersen, supra note 173, at 810 .

267. Republica de Colombia, Corte Constitucional, Sentencia No. T.-523/94, available at http://www.ideam.gov.co:8080/legal/sentens/1994/t-523-1994.html. 
The court said that the State bears the responsibility to protect the constitutional right to a healthy environment. ${ }^{268}$ The State has authority to do this since the "inherent ecological function" of the Social Function Doctrine ${ }^{269}$ means that a private property owner cannot abuse the right to private property by engaging in a use of property that damages a public resource. $^{270}$

Brazil offers a more sweeping example of the current use of the Social Function Doctrine. In addition to social function encompassing ecological aspects, it has also evolved to include the notion that productive use of land must not only respect its ecological function, but also promote respect and dignity for rural workers. ${ }^{271}$ This broadened conception of social function has been termed the "socio-environmental function" of land. ${ }^{272}$ According to one commentator, it not only explicitly rejects the notion that use of land to produce revenue guarantees a fulfillment of land's social function, but even goes so far as to realize that some economically beneficial activities of land may actually undermine the social function of land. ${ }^{273}$ Brazil has further pushed the envelope of Social Function Doctrine by giving it meaning in an urban context. ${ }^{274}$ Vacant buildings in metropolitan Sao Paulo, for example, may be subject to expropriation for not fulfilling their social function. ${ }^{275}$

268. Id. at II.2.C.3. The court there referred to article 366 of the Colombian Constitution (["The general well-being and improvement of the quality of life of the population are social purposes of the state."(Thomas Ruppert trans.)]).

269. Colombian CONST. art. 58.

270. Sentencia No. T.-523/94 (Supreme Constitutional Court of Colombia), available at http://www.ideam.gov.co:8080/legal/sentens/1994/t-523-1994.html.

271. Fernando Mathias Baptista, Reforma Agrária e Função Socioambiental da Terra (2002)(unpublished manuscript on file with authors).

272. See id.

273. Id. (using example of a landowner deforesting land, polluting waterways, causing erosion, excessively using agrochemicals, employing laborers under slave-like conditions with no worker guarantees in order to produce a monoculture exclusively for export and that does not promote accrual of any benefit in the form of essential needs for the community); see also Edésio Fernandes, Law and the Production of Urban Illegality, 13 LAND LINES NEWSLETTER 3 (2001), available at http://www.lincolninst.edu/pubs/pub-detail.asp?id=239 (praising the Brazilian constitution's definition of "social function" as a way to overcome the outdated civil code that "views land and property rights almost exclusively in terms of the economic possibilities granted to individual owners, allowing little room for socially oriented state intervention aimed at reconciling different interests over the use of land and property").

274. CONST. OF BRAZIL art. 182.

275. Id. art. 182(4)III. 


\section{Challenges to the Doctrine from the Trade Regime: Social Function and Regulatory Expropriation}

In addition to covenants, human rights treaties, and cases that apply them, other international laws related to trade are beginning to have a significant role in defining the right to property at the international level. ${ }^{276}$ Key recent international law cases to protect investors focus on the need to pay compensation. ${ }^{277}$ This could present a significant change because it tends to interject multinational non-state corporate interests into the domestic development of policy and law helping to define property rights. ${ }^{278}$ Indeed, at least in Mexico, history suggests that the significance of the Social Function Doctrine has not been lost on corporate property interests. ${ }^{279}$ The contemporary emergence of trade agreements intended to level the playing field for international investors may reawaken this discussion, especially in the face of national policies in Latin America that prohibit treating foreign investors more favorably than their domestic counterparts. ${ }^{280}$

A recent case under the North American Free Trade Agreement (NAFTA) may presage the development of investor-state disputes over the nature of government control of private property. In Metalclad $v$. United Mexican States, arbitration held that the government of Mexico had to pay compensation to a United States corporation because Mexico's actions were "tantamount" to an expropriation and NAFTA forbids this without compensation. ${ }^{281}$ The tribunal noted that Mexico's

276. See Marc R. Poirier, The NAFTA Chapter 11 Expropriation Debate Through the Eyes of a Property Theorist, 33 ENVTL. L. 851, 873-74 (2003); cf. Carlos G. Garcia, All the Other Dirty Little Secrets: Investment Treaties, Latin America, and the Necessary Evil of Investor-State Arbitration, 16 FLA. J. INT'L L. 301 (2004) (noting the dramatic increase of litigation over regulations through use of NAFTA's chapter 11 investor-protection rules and similar rules in the rapidly expanding world of bilateral investment treaties).

277. Poirier, supra note 276, at 852-53.

278. See Errol Meidinger, Property Law for Development Policy and Institutional Theory: Problems of Structure, Choice, and Change, at 29-31 (2003 draft), http://www.law.buffalo.edu' research/workshops/Meidinger.pdf; see also Garcia, supra note 276, at 305 n.4.

279. See, e.g., DEL CASTILLO, supra note 133, at 23-24 (noting that private associations as well as the Secretary of Foreign Relations and the Secretary of Commerce and Industry strongly objected in 1928 to the idea that a landowner had the responsibility to ensure that her or his enjoyment of property also served a social function). See generally Schneiderman, supra note 162.

280. This is known as the "Calvo doctrine," named after an Argentine diplomat and writer, which states that a foreigner shall not be entitled to greater legal protection than nationals of a country. RESTATEMENT (THIRD) OF FoREIGN RELATIONS LAW $\$ 713 \mathrm{cmt}$. g, reporter's note 6 (1987); Schneiderman, supra note 162, at 89-90. The United States has never recognized the validity of the Calvo doctrine, and its legal status is uncertain at the international level. RESTATEMENT (THIRD) OF FOREIGN RELATIONS LAW § 713, cmt. g, reporter's note 6 (1987).

281. Metalclad v. United Mexican States, 40 I.L.M. 36, 50 (2001). 
laws lacked the transparency and clarity that NAFTA seeks in order to protect international investors, ${ }^{282}$ and that local denial of a building permit and state decree of an ecological preserve that permanently prevented completion of a hazardous waste landfill at the heart of the case amounted to an expropriation. ${ }^{283}$

Because of the complicated procedural nature of the case under Mexico's federal system, it did not squarely present the question of whether the regulation of private property for environmental purposes to the extent that all economically beneficial use has been removed would be "tantamount to expropriation" under NAFTA law. However, it is not difficult to imagine a contemporary interpretation of the "social function of property" under domestic law that would uphold the right (and obligation) of the state to regulate the use of private property in order to ensure that its environmental function is maintained, even if it deprived the owner of all economic use. Such an analysis would require an inquiry into the domestic jurisprudence of regulatory expropriation, an area of comparative law that appears to have received little attention.

\section{The Social Function Doctrine in the Neoliberal Era}

The 1980s has been characterized as "the lost decade" by Latin American historians, an era characterized by economic stagnation and social and political unrest. ${ }^{284}$ Globally, the second half of the decade witnessed the collapse of the Soviet Union and the discrediting of the socialist state. ${ }^{285}$ In the 1990 s, neoliberal ideology emerged triumphant and profoundly influenced legal and political developments in the region. ${ }^{286}$ Bilateral donors and multilateral lending institutions such as the World Bank and International Monetary Fund held cash-starved Latin American governments hostage to "structural adjustment" and privatization policies and encouraged legal reforms to back these policies. ${ }^{287}$ Some countries, like Nicaragua and Guatemala had recently emerged from civil wars and were in a position to consider constitutional reforms. Others, like Mexico and Chile, were embarking on economic expansion and seeking to modernize their economies to support free

282. Id. at 49 (para. 88), 50 (para. 99).

283. Id. at 51 (para. 111).

284. Cf. THIESENHUSEN, supra note 2, at 2, 3-4, 21 .

285. Cf, e.g., id. at 4, 14.

286. See, e.g., id. at 13-15.

287. Cf., e.g., id. 
trade agreements that might ultimately lead to a hemispheric free trade agreement of the Americas. ${ }^{288}$

In 2000, the Peruvian scholar Hernando DeSoto authored an influential work entitled "The Mystery of Capital: Why Capitalism Works in the West and Fails Everywhere Else." 289 The book argued that the region's land policy was outdated and failed to promote land markets, which served as the engine of capital formation in developed countries. ${ }^{290}$ The World Bank and other multilateral lending institutions began to promote "market-assisted land reform" as an alternative to expropriation. ${ }^{291}$ These developments all provided opportunities for Latin American nations to consider the contemporary relevance of the Social Function Doctrine. Given these opportunities, we identified two Latin American countries that eliminated the Social Function Doctrine from their constitutions. In other cases, however, more ambiguous results emerged.

Peru stands as an excellent example of a 1990s neoliberal government that effectively eliminated the Social Function Doctrine from its constitution. The Social Function Doctrine first appeared in Peru's 1920 constitution, ${ }^{292}$ and was maintained in its 1933 Constitution. ${ }^{293}$ The 1979 Constitution adopted the term "social interest," but its under-

288. See id. at $4,162$.

289. HeRnando de Soto, The Mystery of Capital: Why Capitalism Triumphs In the WEST AND FAILS EVERYWHERE ELSE (2000).

290. See id. at 164-71.

291. See, e.g., Swaminathan AiYar et al., World Bank, Market-Assisted Land ReForm: A New SOlution to Old PROBlems (1995), available at http://wwwwds.worldbank.org/servlet/WDS_IBank_Servlet?pcont=details\&eid=000094946_01 1018040 92790; The World Bank, News \& Broadcast- World Bank Supports Fiscal Reforms and Rural Land Development in Malawi (Apr. 14, 2004), http://web.worldbank.org/WBSITE/EXTERNAL/ NEWS/0, contentMDK:20192267 menuPK:34463 pagePK:64003015 piPK:64003012 theS. itePK:4607,00.html (last visited Mar. 5, 2006). This focus has led to intense criticism of marketassisted land reforms. See, e.g., Saturnino M. Borras, Jr., Questioning Market-Led Agrarian Reform: Experiences from Brazil, Colombia and South Africa, 3 J. AGRARIAN CHANGE 367 (2003).

292. See Congreso de la República del Perú, http://www.congreso.gob.pe/constitucion.htm (last visited Mar. 5, 2006). This Web site contains links to previous Peruvian constitutions and commentary on them. Regarding the 1920 Constitution of Peru, the site says that "among the social guarantees appears ... the social function of property" ("En las garantias sociales aparecieron las condiciones de trabajo, el salario mínimo, la función social de la propiedad, la conciliación y el arbitraje obligatorio en los conflictos entre el capital y el trabajo."). See CONSTITUCIÓN DE LA REPUBLICA DE PERU art. 38 (1920), available at http://www.congreso.gob.pe/ constitucion.htm ("La propiedad, cualquiera que sea el propietario, está regida exclusivamente por las leyes de la República y se halla sometida a las contribuciones, gravámenes y limitaciones que ellas éstablezcan." ["Property, regardless of its owner, is regulated exclusively by the laws of the Republic and is subject to all contributions, burdens, and limitations established by law." (Thomas Ruppert trans.)]).

293. 1933 CONST. OF PERU art. 31. 
standing appears to be the same, including the familiar Weimar refrain that "property obliges." 294 The year 1993 marked the rise of Alberto Fujimori and neoliberalism in Peru and a new constitution was drafted. The 1993 constitution dropped the obligation language from its property clause and provides simply that "property is exercised in harmony with the common good and within the confines of the law."295 Thus in Peru the role of property apparently went from the social constitutional model of "positive obligation" to the neoliberal model of a "negative obligation" to not use land in violation of the law. The Social Function Doctrine, however, dies hard. Since the flight of Fujimori and Montesinos from Peru, the Social Function Doctrine again is the law of the land. ${ }^{296}$

Mexico, where the Social Function Doctrine has its Latin American roots, presents another case of the effect of neoliberal thought on the constitutional support for the Social Function Doctrine. In 1992, Mexican president Salinas de Gortari signed a decree that modified article 27 of the Mexican constitution. ${ }^{297}$ The changes eliminated a requirement of use or exploitation from the legal definition of small, rural land holdings protected from expropriation. ${ }^{298}$ More than one

294. CONST. OF PERU OF 1979 art. 124 ("La propiedad obliga a usar los bienes en armonía con el interés social. El Estado promueve el acceso a la propiedad en todas sus modalidades. La ley señala las formas, obligaciones, limitaciones y garantias del derecho de propiedad." ["Property obliges its use in harmony with the social interest. The State promotes access to all forms of property. The law determines the forms, obligations, limitations, and guarantees of the right to property." (Thomas Ruppert trans.)]).

295. 1993 CONST. OF PERU art. 70.

296. See, e.g., Sentencia 0048-2004-PI/TC (Peruvian Constitutional Tribunal, Apr. 1, 2005). This decision notes:

When our Constitution guarantees the inviolable right to property and indicates that this right should be exercised in harmony with the public good and within the limits of the law, the Constitution does nothing more than refer to the social function that the law of property has as part of its esisence.

Id. para. 78 (emphasis added).

297. Decreto por el que se reforma el artículo 27 de la Constitución Política de los Estados Unidos Mexicanos [Decree to reform article 27 of the Constitution of Mexico], Diario Oficial de la Federación, [D.O.] 6 de Enero de 1992 [Jan. 6, 1992] (Mex.), available at http://www.juridicas. unam.mx/infjur/leg/constmex/pdf/rc120.pdf.

298. Language before January 3, 1992, decree (published Jan. 6, 1992):

XV. Las comisiones mixtas, los gobiernos locales y las demás autoridades encargadas de las tramitaciones agrarias, no podrán afectar, en ningún caso, la pequeña propiedad agrícola o ganadera en explotación e incurrirán en responsabilidad, por violaciones a la Constitución, en caso de conceder dotaciones que la afecten.

Se considerará pequeña propiedad agrícola la que no exceda de cien hectáreas de riego o humedad de primera o sus equivalentes en otras clases de tierras en explotación. ["The joint commissions, local governments, and other authorities in charge of procedures related to agricultural land may in no case expropriate small farms or cattle ranches THAT ARE ACTIVELY BEING EXPLOITED; any authorities 
commentator has suggested this means that article 27 no longer contains the positive obligations of productive use of land traditionally included in the Social Function Doctrine. ${ }^{299}$ These changes have been directly attributed to a desire to conform the constitution and laws of Mexico to the neoliberal model to facilitate free trade agreements such as NAFTA. $^{300}$ Such changes have prompted strong criticism as well as calls for continued adherence to the Social Function Doctrine in Mexico. ${ }^{301}$ This may also indicate that Mexico is now more willing to abandon its traditional claim that expropriations due to land reform may be compensated at levels less than that of other types of expropriation. ${ }^{302}$

that grant titles that conflict with such lands will be held responsible for constitutional violations.

A small agricultural property is one that does not exceed 100 hectares of irrigated or moist soils or the equivalent in other classes of soils." (Thomas Ruppert trans.)]

1917 CONST. OF MEXICO art. 27.XV, available at http://www.cervantesvirtual.com/servlet/ SirveObras/08146396711992773087857/p0000001.htm\#I_1_(emphasis added).

Language after January 3, 1992, decree (published Jan. 6, 1992):

XV. En los Estados Unidos Mexicanos quedan prohibidos los latifundios.

Se considera pequeña propiedad agrícola la que no exceda por individuo de cien hectáreas de riego o humedad de primera o sus equivalentes en otras clases de tierras.

["Latifundos are prohibited in the United Mexican States.

A small agricultural property is one that does not, per person, exceed 100 hectares of irrigated or moist soils or the equivalent in other classes of soils." (Thomas Ruppert trans.)]

Article 27.XV, 1917 Constitution of Mexico with January 3, 1992 reforms, available at http:// www.pa.gob.mx/publica/pa07ba.htm\#XIX.

299. Francisco M. Hernández Báez (Magistrado del Tribunal Unitario Agrario, Distrito 04), Función Social de la Propiedad Rural, http://www.tribunalesagrarios.gob.mx/ensayos/ FUNCION\%20SOCIAL\%20DE\%20LA\%20PROPIEDAD\%20RURAL.htm (last visited Mar. 5, 2006) (arguing that exclusion of the phrase "in use" from subpart XV of article 27 of the constitution indicates that landowners are now free to either use their rural lands or leave them idle)(Thomas Ruppert trans). Compare art. 27, XV before modification in January 1992, with art. 27, XV, after January 6, 1992 decree, http://www.pa.gob.mx/publica/pa07ba.htm\#XIX; see also Herbert C. de Grammont, Política Agraria y Estructura Territorial, available at http://www.pa.gob.mx/publica/pa070204.htm (last visited Jan. 31, 2006).

300. Herbert C. de Grammont, Política Agraria y Estructura Territorial, http://www.pa.gob. $\mathrm{mx} / \mathrm{publica} / \mathrm{pa070204.htm} \mathrm{(last} \mathrm{visited} \mathrm{Mar.} \mathrm{5,} \mathrm{2006).}$

301. See, e.g., id.; Francisco M. Hernández Báez (Magistrado del Tribunal Unitario Agrario, Distrito 04), Función Social de la Propiedad Rural (undated), http://www.tribunal esagrarios.gob.mx/ensayos/ensayos.htm. One might easily see these reforms by Salinas as a way to heal the rift that began in 1938 when, after expropriations in Mexico affecting U.S. interests, the United States insisted that international law requires "prompt, adequate and effective compensation." RESTATEMENT (THIRD) OF FOREIGN RELATIONS LAW § 712, reporter's note 1 (1987). Mexico, however, insisted that international law only required that foreigners be treated equally with nationals. $I d$.

302. See Restatement (ThIRD) OF Foreign Relations LAW $\$ 713$, reporter's note 3 (noting that Mexico and the United States began a disagreement in 1938 about the compensation necessary for expropriations motivated by land reform). 
Other countries undertaking constitutional reforms have not eliminated the language of social function but have altered its language. For example, Nicaragua first introduced the phrase social function into its constitution in $1939{ }^{303}$ which was retained by the 1950 constitution. ${ }^{304}$ The Sandinista Constitution of Nicaragua of $1987^{305}$ further strengthened the social function of land. ${ }^{306}$ The 1993 reforms modified the social function language in Nicaragua's constitution, ${ }^{307}$ but the import of such changes would require in-depth research into the domestic laws and court decisions in Nicaragua.

Thus, despite some inroads, the Social Function Doctrine remains a powerful force in the region, especially in countries such as Brazil, ${ }^{308}$ Colombia, ${ }^{309}$ and Venezuela, ${ }^{310}$ where the promise of agrarian reform has never been realized and inequitable land distribution remains a fact of economic and social life. ${ }^{311}$ In Brazil and Venezuela the resurgence of

303. Article 65 of the 1939 constitution observed, "Property, by virtue of its social function, imposes obligations." 1939 CONST. OF NICARAGUA art. 65 , available at http://www. cervantesvirtual.com/servlet/SirveObras/02450554214134274754491/index.htm ("La propiedad en virtud de su función social impone obligaciones.").

304. 1950 CONST. OF NICARAGUA art. 65, available at http:/www.cervantesvirtual.com/ servlet/SirveObras/09253063411069473087857/p0000001.htm\#I_1_.

305. José F. Palomino Manchego, La Constitucion Española de 1978 y su Influencia en el Ordenamiento Constitucional Latinoamericano 13 (presentation to the VIII Congreso Iberoamericana de Derecho Constitucional, Dec. 3-5, 2003, Sevilla, Spain) (noting that the Sandinistas consecrated their revolution with the establishment of the 1987 constitution).

306. 1983 CONST. OF NICARAGUA art. 103, available at http://www.cervantesvirtual. com/servlet/SirveObras/80295066320571495200080/index.htm ("El Estado garantiza la coexistencia democrática de las formas de propiedad pública, privada, cooperativa, asociativa y comunitaria; todas ellas forman parte de la economía mixta, están supeditadas a los intereses superiores de la Nación y cumplen una función social." ["The State guarantees the democratic coexistence of public, private, cooperative, associative, and community-based forms of property; all these forms of property form part of the mixed economy and are subject to the superior interests of the Nation and serve a social function." (Thomas Ruppert trans.)]).

307. See, e.g., ConST. OF Nicaragua art. 5 ("Las diferentes formas de propiedad ... deberán cumplir una función social.”); id. art. 44 ("En virtud de la función social de la propiedad, este derecho está sujeto, por causa de utilidad pública o de interés social, a las limitaciones y obligaciones que en cuanto a su ejercicio le impongan las leyes.") ["The different forms of property ... should fulfill a social function."], id. art. 44 ("By virtue of the social function of property, this right is, due to public utility or the social interest, subject to the limitations and obligations that the law provides according to the use of the land in question.") (Thomas Ruppert trans.)]).

308. See supra notes 193-201, 269-273 and accompanying text.

309. See supra notes 202-219, 265-268 and accompanying text.

310. See supra notes $220-228$ and accompanying text.

311. Other Latin American countries also sometimes seem reluctant to alter application of the Social Function Doctrine and the substantive differences it creates in laws regarding expropriation. For example, in Chile a government subcommittee expressed the belief that any imposition on land provoked by application of the Social Function Doctrine does not require indemnification. See MARIO VERDUGO MaRINKOVIC, INFORME EN DERECHO (2004), http://www. minmineria.cl/img/informeconstitucional.pdf. 
populist governments bent on completing the unfinished business of land reform has breathed new life into the moribund application of the Doctrine. The World Bank has been encouraged to recognize the continuing role that the Social Function Doctrine has to play in land reform. ${ }^{312}$ And even the neoliberal model of Peru seems unwilling to bid a final farewell to the Social Function Doctrine.

\section{CONCLUSION}

A major work by a Spanish author begins, with feigned exasperation, by asking: "Another book on the social function of property?"313 To English-language legal scholars, this apparent need for Spanish-language legal scholars to justify delving into what is apparently well-traveled ground in the civil law comes as a complete surprise. Our research yielded a marked paucity of English-language legal literature concerning a doctrine that apparently fascinates our Latin American and continental European counterparts in the civil law. We find it remarkable that a doctrine so fundamental to private and public law in many countries in the world has received so little attention in comparative legal literature in the United States. When it is addressed, it is usually in passing in historical and development literature on agrarian reform. This is even more remarkable given the way that this doctrine helps illuminate divergent political and social philosophies over the role of land in society, philosophies that have spawned revolutions, affected development and may ultimately have profound effects on international and comparative law in a globalized world.

In Europe the Social Function Doctrine appears to have developed as a response to the Napoleonic-era liberal bias of the private law governing property, and in the broader context of the emergence of the bureaucratic state and the discourse of socialism on the continent. Its actual application to state-individual property relations appears more nuanced, and appears to focus more on the state right to regulate private property. In developing Latin America, however, the utility of the doctrine has been more apparent, and its use more heavy-handed. There, the Social Function Doctrine justifies state intervention to correct one of the abiding truths of the region, the inequitable distribution of land made all the more stark by unrelenting poverty and concomitant landlessness.

312. Alain de Janvry \& Elisabeth Sadoulet, Land Reforms in Latin America: Ten Lessons Toward a Contemporary Agenda $\S 6.2$ (2002), http://are.berkeley.edu/\%7Ealain/ (paper prepared for presentation at the World Bank's Latin American Land Policy Workshop, Pachuca, Mexico, June 14th 2002).

313. Colina GAREA, supra note 145 , at 11. 
Despite the abundance of foreign language literature on the "social function of property," its contours remain obscure and its character evolutionary. This may be attributed to the nature of the civil law, and the absence of precedential jurisprudence by courts, leaving scholars with the task of interpreting the phrase, but providing little in the way of application of the doctrine to specific facts. And it may be attributable to our own legal cultural bias and lack of training in the civil law tradition. Clearly, however, the doctrine sits as an overlay on the civil law of property that cannot be explained simply as another way to rationalize expropriation. Instead, it represents a conceptually distinct view of the role of property in society, and the role of the state in intervening in property relations. 